\title{
Smoking Status among Medical Students of Near East University in Nicosia
}

\author{
Özen Asut (1) \\ Department of Public Health, Near East University Faculty of Medicine, Nicosia, Cyprus
}

ORCID ID of the author: Ö.A. 0000-0002-9604-4037.

Cite this article as: Asut Ö. Smoking Status among Medical Students of Near East University in Nicosia. Cyprus J Med Sci 2019; (Suppl I): I-2I.

\section{BACKGROUND/AIMS}

The objectives of the present study were to evaluate the tobacco prevalence status of Near East University (NEU) Medical school students and to investigate the associations of tobacco use with medical education and other related factors.

\section{MATERIAL and METHODS}

This cross-sectional study was conducted among all the multinational medical students of NEU in February 2018. A questionnaire was administered to the students under direct observation. Data were analyzed using the Statistical Package for the Social Sciences version 18.0.0 software (IBM Corp.; Armonk, NY, USA). A p value $<0.05$ was considered as significant.

\section{RESULTS}

The study targeted all the medical students attending medical school in the educational year 2017-2018. Of a total of $137 \mathrm{I}$ medical students, II54 (84.2\%) were included in the study, of which $48.9 \%$ were males and $51.1 \%$ were females. Current smokers were $33.7 \%$ with $26.5 \%$ daily smokers. Lifetime smoking was $40.7 \%$ with the inclusion of former smokers. Of the II54 students, $42.1 \%$ and $25.8 \%$ were male and female smokers, respectively. There was a significant difference between the two genders, with males smoking more. Regarding admission to medical school, there was a significant difference between the genders, with smoking initiation of women being higher than that of men during medical education. Of the male smokers, $61 \%$ had started smoking before admission to medical school. A comparison of the countries of origin revealed a significantly higher frequency of smoking among Turkish Republic citizens than all other country citizens.

\section{CONCLUSION}

Smoking prevalence among medical students was found to be high, with males smoking significantly more than females. Medical education did not appear to influence the smoking status of medical students, taking into account the high frequency similar to other university students. Earlier and more efficient tobacco control and cessation education and interventions are needed throughout medical education for better role model doctors for the community in the future.

Keywords: Smoking, tobacco control, medical curriculum, medical students

\section{INTRODUCTION}

Smoking is one of the leading causes of all deaths and the second major preventable cause of death worldwide, ending $>7$ million lives/year. By 2030, the estimated death toll will increase to approximately 8 million/year (I). One of the best ways to fight against smoking is by counseling provided by general practitioners and other physicians in public health settings (2). However, smoking prevalence among doctors (3) and medical students (4) continues to remain relatively high in a number of countries.

Smoking is a key issue of the medical profession, negatively affecting just about every organ in the body, often ending up with cancers and other incurable diseases, as well as diminishing the quality of life (5-9). Since the first tobacco report of the US Surgeon General in 1964, >20 million premature deaths can be attributed to tobacco consumption, as a result of smoking toxicity due to the 7000 chemical compounds and 69 carcinogens in tobacco smoke $(8,10-13)$.

Research has shown that physicians and medical interventions can be very effective in the cessation of smoking (I4). Hence, doctors should set examples by presenting a non-smoker environment since it is well known that non-smoking doctors have a better chance to succeed in promoting smoking cessation $(15,16)$. 
A review published in 2007 investigated 81 studies published between 1974 and 2004 about smoking among health professionals to determine smoking trend changes. Smoking addiction varied widely through the years and among countries; nevertheless, smoking among health workers was found to be highly prevalent in a number of countries (3).

Medical school students, who are the focus of our research, were studied in an international review of tobacco smoking conducted in 2007. The prevalence of smoking was found to range from $3 \%$ in the USA to $58 \%$ in Japan (4).

In a 2007-2008 study in the Turkish Republic of Northern Cyprus (TRNC), the prevalence of lifetime smoking among university students was found to be $69.5 \%$ (17). There is no study conducted yet on the smoking status of only medical students in the TRNC. On the other hand, the prevalences among medical students in various surveys were found to range between $30 \%$ and $40 \%$ in Turkey (|8-2I)

Some studies on medical students in Nigeria revealed lifetime tobacco used to be $9.6 \%-10.5 \%(22,23)$. A 2004 study in Syria on cigarette smoking among university students found the prevalence to be $22.8 \%$ and a 2007 study on medical students to be $10.9 \%(24,25)$.

In Jordan, studies on university students found the prevalences to be $28.6 \%$ in 2002 and $35 \%$ in 2008 (26, 27). The prevalences were found to be lower with $26 \%$ for males and $7 \%$ for females in a study among medical students in Jordan (28).

A cohort study conducted in Turkey in 2006 to follow-up the incidence of smoking during the medical education period found that $30 \%$ of students who were non-smokers at the time of registration to medical school have become smokers by the time they reached the final grade. Most new incidences occurred during the first three grades (29). In addition, the attitudes of medical students toward anti-smoking activities were not necessarily positive $(30,31)$.

Using tobacco products other than cigarettes is a worldwide issue that adds up to the cigarette epidemic. Water pipe (narghile and hookah) is the second most consumed international tobacco product (32). It is especially prevalent among adolescents and university students in many countries, including Turkey, Middle East countries, and the USA (33). Studies in Turkey showed that $32.7 \%$ of the university students and $28.6 \%$ of the medical students were using water pipes $(34,35)$. Other tobacco products used, even if not smoked so regularly, are cigars medwakh (dokha) and pipe (36-38). E-cigarettes or vaporizers are marketed as safer, more environment friendly alternatives to tobacco [39]. Indeed, their prevalence is on the rise, but there is no evidence as yet to consider them as healthier $(39,40)$.

According to our review of the current literature, to the best of our knowledge, there are no studies on tobacco conducted exclusively among medical students in any of the TRNC universities. The aims of the present study were to determine the prevalence of smoking and other tobacco products use among medical students and to find clues for the effect of medical edu- cation and other related factors on smoking habits among medical students enrolled in Near East University (NEU).

Our study aims at determining the smoking status among medical students in one of North Cyprus's (TRNC) universities, NEU Medical School, in an attempt atforming an idea about how medical education, background, family smoking status, and some other factors affect smoking habits of those students. There are no published studies that have been conducted exclusively on medical students in any of the Northern Cyprus universities. Our aim is to find medical students' smoking status in a university of the TRNC as part of the collective work for decreasing tobacco smoking among medical students who will be future doctors.

\section{Short-Term Aims}

I. To determine the prevalences of smoking and other tobacco products use among medical students,

2. To find some clues about the influence of medical education on smoking habits of these students,

3. To determine the association between some socio-demographic characteristics and smoking status of medical students.

\section{LONG-Term Aims}

I. To raise awareness about the problem of smoking among medical students in general,

2. To provide data for planning new tobacco intervention means on smoking directed to students in medical schools and other university students,

3. To provide data to assist developing activities aiming for tobacco-free university campuses in the TRNC.

\section{Background}

Smoking is one of the leading causes of death worldwide, ending up with the loss of 7 million lives/year; by 2030, it is estimated that tobacco-related deaths will increase to approximately 8 million/year (I). Counseling provided by general practitioners and other physicians is an evidence-based measure for tobacco cessation (2). It is logical to assume that doctors in general, along with medical students, know best about the negative effects of smoking on leading a healthy life; nevertheless, smoking prevalence among doctors and medical students remains relatively high $(3,4)$. Thus, research on tobacco use among medical professionals continues to be of utmost importance for public health in many countries.

\section{History of Tobacco in the World and in Turkey}

The origin of tobacco is a matter of controversy; the dispute is on whether it is Asian or American. Tobacco was brought to Europe by ships of Christopher Columbus and friends (4I). Columbus has witnessed people smoking tobacco by pipes and also chewing tobacco leaves. Tobacco was named after the pipes called tobacco, which were used for smoking (42). Indians were smoking dried tobacco called petom using the pipes or consumed tobacco by rolling it within tobacco leaves (43). Tobacco consumption increased rapidly after the discovery of its influence on pleasure (4I).

Tobacco agriculture and consumption were prevalent in Turkey during the Ottoman Empire and after the establishment of the Turkish Republic (TR) (44). 


\section{Constituents of Tobacco Smoke}

The most frequently consumed form of tobacco is cigarette smoking. Cigarette smoke contains $>7000$ chemicals, including 69 compounds known to have carcinogenic effects and 250 other toxins (10). The cigarette ingredients may be in the gas or particle phase. Tobacco smoke also contains oxidants and free radicals that initiate or progress oxidative damage (45).

Tobacco used in the manufacture of cigarettes contains $0.5 \%-$ $8 \%$ nicotine in the particle phase. Nicotine is highly addictive and gives the smoker the feeling of being calm. Tobacco smoke containing nicotine is inhaled into the lungs and reaches the brain in a matter of $6 \mathrm{~s}$ (12). Nicotine has effects on the psychiatric level; it is a stimulant in low doses, but has a paradoxical depressant effect in large doses, due to the blockage of the flow of signals between nerve cells. In much larger doses, nicotine is lethal by affecting body heat regulation, blood vessels, and hormones (I3).

The carcinogenic and other ingredients in tobacco smoke include nicotine, tar, carbon monoxide, formaldehyde, ammonia, hydrogen cyanide, arsenic, and dichlorodiphenyltrichloroethane, as well as nitrosamines, aromatic hydrocarbons, arsenic, benzene, cadmium, polonium-210, chromium, acrolein, acetaldehyde, hydrazine, nickel, lead, cobalt, and beryllium. Polonium-2I0 and lead-210 in smoke are radioactive ingredients emitting alpha particles. These radioactive isotopes deposit in the lungs and reach other organs and tissues by circulation $(I 1,46)$. The level of ionizing radiation has been shown to be higher in student rooms where smoking is prevalent than in non-smoking rooms (47).

\section{Forms of Tobacco Use}

Tobacco is manufactured from Nicotiana tabacum and Nicotiana rustica plants. Different forms of tobacco products include cigarettes, pipes (medwakh and dokha), cigars, bidi (handrolled cigarettes), snuff, cretex, smokeless tobacco (paan and gutkha), chewing tobacco, water pipe (shisha, narghile, argila, and hookah), vaporizer, or e-cigarettes. In Turkey, the most prevalent form of tobacco use is cigarette smoking; less consumed forms are hookah, pipes, and cigars and, in some locations, hand-rolled tobacco $(48,49)$.

Hookah (water pipe and narghile) consumption is a form of tobacco use prevalent in Turkey, India, and Iran. Tobacco from the N. tabacum family is consumed in hookah use (49).

Pipe tobacco is manufactured from Virginia, Burley, Kentucky, and Maryland tobacco. The tobacco is subjected to other procedures for flavoring, such as aromatization (50).

Cigar is a tobacco product $>3 \mathrm{~g}$ obtained by hand or machinery rolling of cigar or cigarette tobacco. Tobacco products of the same form <3 g are called cigarillos (5I).

Snuff is a tobacco product of high nicotine levels in powder form and mixed up with aromatizing ingredients, such as bergamot, clove, cinnamon, and carbonate. It is consumed by inhalation through the nostrils (52).

Chewing tobacco is smokeless tobacco extracted from N. rustica L. and is prevalent in the southeastern part of Turkey. This form of tobacco is consumed by keeping it in the mouth for some time and spitting out afterwards (53).

\section{Nicotine Addiction and Health Consequences of Tobacco Use}

According to the World Health Organization, tobacco is the second major preventable cause of death and the fourth most common risk factor for disease worldwide, killing 100 million people in the 20th century and estimated to kill approximately I billion in the 2lst century. It claims approximately 7 million lives/ year; by 2030, it is estimated that the death toll will increase to 8 million/year (I). Smoking is a key issue in the medical profession, being that the doctors' role is essential for the prevention of smoking in the community (5), and it is always taken into consideration in the development of overall public health policy. Smoking negatively affects just about every organ in the body (6), along with the quality of life (7).

Smokers have a higher mortality rate at all ages and also have more periods of life with acute or chronic diseases. They have more leaves from their jobs or school attendance. Additionally, lifelong cigarette smokers have a $50 \%$ chance of dying of health problems related to tobacco use. Approximately half of the mortality from smoking is premature deaths of the productive ages. The life expectancy of smokers is approximately 10 years earlier on average than that of non-smokers according to the current research (54).

Unless effective tobacco control measures are taken, the present 7 million death toll will increase up to 10 million in the next 25-30 years, and most of the deaths will be in developing countries (I).

Nicotine is a naturally occurring toxic chemical in tobacco plants causing addiction. It is a strong psychomotor stimulant causing physical and psychological dependence.

Addiction is termed substance dependence by the American Psychiatric Association (APA). Diagnostic and Statistical Manval of Mental Disorders IV criteria of substance dependence have been defined precisely by the APA, which are all relevant for nicotine addiction $(55,56)$.

Addiction is defined as a maladaptive pattern of substance use leading to clinically significant impairment or distress, as manifested by three (or more) of the following (criteria) occurring any time in the same 12-month period:

I. Tolerance, as defined by either of the following:

a. A need for markedly increased amounts of the substance to achieve intoxication or the desired effect,

b. Markedly diminished effect with continued use of the same amount of the substance.

2. Withdrawal, as manifested by either of the following:

a. The characteristic withdrawal syndrome for the substance,

b. The same (or closely related) substance is taken to relieve or avoid withdrawal symptoms.

3. The substance is often taken in larger amounts or over a longer period than intended.

4. There is a persistent desire or unsuccessful efforts to cut down or control substance use.

5. A great deal of time is spent in activities necessary to obtain the substance, such as visiting multiple doctors or driv- 
ing long distances, use the substance, such as chain-smoking, or recover from its effects.

6. Important social, occupational, or recreational activities are given up or reduced because of substance use.

7. Substance use is continued despite knowledge of having a persistent physical or psychological problem that is likely to have been caused or exacerbated by the substance (for example, current cocaine use despite recognition of cocaine-induced depression or continued drinking despite recognition that an ulcer was made worse by alcohol consumption).

Smoking is especially hazardous to the respiratory system, causing lung cancer, chronic obstructive pulmonary disease (COPD), and other diseases. Smokers are 12-13 times more likely to die from COPD than non-smokers $(8,9)$. Smoking also triggers asthma attacks and facilitates lung fibrosis $(8,9)$. People who smoke even $<5$ cigarettes/day can develop early signs of cardiovascular disease. Smoking damages blood vessels and may cause blockage of the blood vessels that reduces the blood flow to the organs and skin, causing early aging, stroke, and coronary artery disease (8).

Smoking is a major risk for cancer in almost all the organs and tissues of the body, including oropharynx, larynx, trachea, esophagus, stomach, colon (colorectal), liver, pancreas, bone marrow (acute myeloid leukemia), bladder, uterine cervix, kidney, and ureter. Tobacco smoke also increases the risk of dying from cancer and other diseases as well in patients with cancer and survivors of cancer. If nobody smoked, one of every three cancer deaths in the USA would have been prevented $(8,9)$.

\section{Cessation Therapy}

The attitudes and behaviors of parents and other role models play crucial roles in adopting, continuing, and quitting of tobacco and other addictions, especially of adolescents. Therefore, younger individuals should be protected from the negative influences of smokers in their vicinity. Children and young people are recommended to be evaluated with their parents in dependency prevention programs, especially during quitting efforts (57-59).

The dependent person is strongly in need of using the substance either as a reward reinforcer or as prevention of the negative symptoms of withdrawal (60). Tobacco dependency is measured by the Fagerström Test for Nicotine Dependence and European Medical Association on Smoking or Health dependency test $(61,62)$.

The evidence-based treatments for smoking addiction are cognitive and behavioral approaches and pharmacotherapy. Counseling the patients on the health consequences of smoking on withdrawal symptoms and tobacco dependency treatment are important aspects of cessation programs, as well as preventing relapse. The success of cessation treatment depends on relieving the withdrawal symptoms for which the first-line pharmacological agents are nicotine replacement therapy, bupropion, and varenicline (63). Combination therapies are available for serious nicotine addiction cases. There are also second-line pharmacological agents as well for the treatment of nicotine dependency, including nortriptyline, clonidine, rimonabant, and nicotine vaccine (64).

\section{Global Tobacco Control Measures}

Tobacco control covers the strategies for improving public health by supply reduction and demand reduction measures regarding the use of tobacco products. The preventive or harm reduction measures from the risks of tobacco smoke by decreasing tobacco consumption and exposure to passive smoking are the most significant of these strategies $(59,65)$.

The WHO Framework Convention on Tobacco Control (FCTC) has been introduced by the WHO to combat the global tobacco epidemic. The Convention entered into force on February 27, 2005-90 days after it had been acceded to, ratified, accepted, or approved by 40 states. The FCTC had been signed by 181 parties and approved by 168 countries worldwide by 2016 .

Core demand reduction provisions in the WHO FCTC (articles 6-14) include price and tax measures and non-price measures to reduce the demand for tobacco, such as protection from exposure to tobacco smoke; regulation of the contents of tobacco products; regulation of tobacco product disclosures; packaging and labeling of tobacco products; education, communication, training, and public awareness; tobacco advertising, promotion, and sponsorship; and demand reduction measures regarding tobacco dependence and cessation. Core supply reduction provisions in the WHO FCTC (articles 15-17) are measures for illicit trade in tobacco products, sales to and by minors, and provision of support for economically viable alternative activities (65).

More than I billion people worldwide are currently tobacco product consumers, with rapidly increasing frequencies in developing countries as a consequence of the population growth and promotive efforts of the tobacco industry. The six most effective policies that can curb the tobacco epidemic in line with the FCTC are outlined in the WHO's M-POWER strategy introduced in 2008: Monitoring tobacco use and prevention, Protecting people from environmental tobacco smoke, Offering help to quit tobacco use, Warning people about the dangers of tobacco, Enforcing bans on tobacco advertising, promotion, and sponsorship, and Raising taxes on tobacco (66). One-third of the world's population (2.3 billion people) is currently covered by at least one effective tobacco control measure.

\section{Tobacco Dependency among Physicians and Medical Students}

The tobacco dependency among physicians is an important factor influencing the general population regarding the attitudes toward tobacco use. The tobacco dependency of physicians may affect their attitudes and functions as role models negatively and may decrease their sensitivity for the risks of tobacco smoking and their behaviors toward informing their patients on the hazards of tobacco use (67).

Tobacco addiction prevalences have been found to be high among male physicians in Turkey during the 1990s. The study by Kosku et al. (67) in 1994 revealed a prevalence of $40 \%$ among residents and $32 \%$ among specialists of the Thorax Association in Turkey. Another study in 1994 found a smoking prevalence of $52.8 \%$ among male doctors and $41 \%$ among female doctors (68). A 2003 study in Hacettepe University Medical School showed a prevalence of $37.2 \%$ among academic personnel. The prevalence of smokers among Ondokuz Mayıs University physicians was found to be $31.9 \%$ (69). 
Other country results regarding smoking among physicians revealed varying prevalences: $27.1 \%$ male Japanese physicians and $6.8 \%$ female Japanese doctors (70); 34\% French general practitioners (7I); $22 \%$ Danish health workers (72); and $15.8 \%$ Israeli physicians (73). There appears to be a need for further education of both the medical doctors and students on the tobacco issue, as well as implementing methods for cessation (74).

\section{Physicians' Responsibility on Tobacco Control}

The best practice is non-smoking doctors. Smoking physicians are not convincing when speaking against smoking (54). While taking a tobacco history, the physician should be aware that only taking a thorough history is capable of quit rates of $1 \%-3 \%$ (55).

Smoking is the main issue in the medical profession, with the doctors' role being essential for the prevention of smoking in the community, which should always be considered in the development of overall public health policy (5). Researchers have shown that medical interventions can be very effective in promoting cessation of smoking (13). Physicians are looked up to by the community, patients, and colleagues. It is only logical for doctors to set examples by presenting a non-smoker environment in their clinics, offices, vehicles, and private residences (14). Since 1976, it was suggested that non-smoking doctors have a better chance to succeed in promoting smoking cessation (I5). A review published in 2007 (3) searched through 81 studies published between 1974 and 2004 about smoking among health professionals to determine smoking trend changes according to time and place (country) and has concluded that even though smoking habits vary widely through the years and among countries, still, it is not uniformly low from an international perspective.

The success of quitting programs is directly related to the intensity of physician advice. The results of studies analyzing short counseling show mean quitting rates of $5 \%(3 \%-13 \%)$ compared with those of intense interventions with mean quitting rates of $29 \%(13 \%-40 \%)(75,76)$.

\section{Medical Students and the Tobacco Issue}

Medical school students are the focus of our research since they will later become physicians themselves, and it is prudent to address smoking behaviors among medical students before preparing them to become the next health promoters who are required also to promote and help smoking cessation in the community.

According to an international review of tobacco smoking among medical students (4), which was conducted in 2007, the prevalence of smoking was found to range from 3\% in the USA to a whopping 58\% in Japan, suggesting that the smoking doctor phenomenon is going to prevail for some more time.

On the other hand, medical education worldwide presents a need in general for more comprehensive tobacco programs in the curricula. A study in Cairo revealed that only $34 \%$ of the medical students stated that they had tobacco control education in their medical education curriculum (77).

Our study focuses on the international program in the medical school of NEU in Northern Cyprus. Students in the program come from different countries and backgrounds, but the most frequent five nationalities found were Northern Cypriot, Turkish, Nigerian, Syrian, and Jordanian. The prevalence of lifelong smoking among university students in Northern Cyprus in 2010 was found to be $69.5 \%$ [16]. To the best of our knowledge, there is no study conducted on medical students cigarette smoking status in Northern Cyprus, whereas the prevalences among medical students were found to range approximately between $30 \%$ and $40 \%$ in Turkey (17-19). In Nigeria, one study on university students revealed the lifetime use of tobacco to be $10.5 \%$ (22), and another study in a different university found the lifetime use of tobacco to be $9.6 \%$ (23). In Syria, a study discussing cigarette smoking among university students in 2004 found that the prevalence was 22.8\% (24), and another study with medical students in 2007 found that the prevalence was $10.9 \%$ (25). In Jordan, a 2002 study (26) in one university found that the prevalence among their students was $28.6 \%$, whereas another study in 2008 (27) found that the prevalence was 35\%. A study (28) that searched for the prevalence among medical students at one university in Jordan found that the prevalences were $26 \%$ among male and $7 \%$ among female students.

A cohort study conducted in Turkey in 2006 to detect the incidence of smoking during the medical study period found that $30 \%$ of students who were non-smokers at the time of registration to medical school had become smokers by the time they reached the final grade, and that most new incidences occurred during the first three grades (29). This suggests that university education in general might be a factor for adoption of the smoking habit, and that medical education is insufficient for raising awareness among students toward the hazards of smoking and preventing new incidences among them. Not helping the medical education image is the fact that the attitudes of medical students toward anti-smoking efforts are not 100\% pro (30). Medical students are subject to the same factors that could lead their equals from the same age group into smoking, such as peer pressure, family member smoking, stress, and depression (3I).

Using other tobacco products is a worldwide issue that adds up to the original and bigger cigarette epidemic. Water pipe (narghile) is considered the second most prevalent international smoking fad that is not showing any sign of fading away (32). It is especially prevalent among adolescents and university students and in many countries, including Turkey, the Middle East countries in Asia, and the USA (33). In Turkey, a study showed that $32.7 \%$ of the university students and $28.6 \%$ of the medical students were using water pipe (34). Many university students who either smoked or did not smoke water pipe have very big misconception about the harmful aspects of water pipe (35).

Other alternative tobacco products use of interest, even if not smoked so regularly, are cigars (36) and medwakh (dokha) (37), which is a long wooden smoking pipe used in Iran and in parts of the Arab Gulf states. Pipe smoking is not as prevalent any more as it used to be (38). E-cigarettes or vaporizers (39) are marketed as a safer, more environment friendly alternative to tobacco. Indeed, their prevalence is on the rise, but there is not enough evidence to consider them as either healthier or more harmful than cigarettes to overall health (40).

The aim of the present study was to determine the prevalence of smoking among medical students in one of the Northern Cyprus 
universities to contribute to the collective international research about this particular issue. We will also search for alternative tobacco product smoking trends, the influence of family members' smoking status on medical students, passive smoking, and attitudes of medical students toward tobacco control measures.

\section{MATERIAL and METHODS}

\section{Time and Location}

The study was conducted among medical students attending the school of medicine at NEU in Nicosia, Northern Cyprus during November 2017 and December 2017 and January 2018 and February 2018.

\section{Type of Study}

This was a cross-sectional study.

\section{Participants of the Study}

The study targeted all the medical students attending the medical school in the educational year 2017-2018. Of a total of I37| medical students, II54 (84.2\%) participated in the study.

\section{Variables of the Study}

\section{Independent variables}

- Socio-demographic features, such as age, sex, grade, nationality, residence, duration of residence in Cyprus, economic status, form of payment for health care

- Exposure to environmental tobacco smoke

- Smoking among family members

\section{Dependent variables}

- Smoking status

- Amount of tobacco consumed

- Duration of smoking

- Nicotine dependence/time of first cigarette smoked

- Use of tobacco products other than cigarettes

- Experience of cessation treatment

- Status of passive smoking

- Smoking initiation time in relation to admission to medical school

- Quitting attempts, quitting methods, and quitting success

- Attitudes toward banning smoking in closed public areas

- Attitudes toward doctors being role models by not smoking

\section{Method of Data Collection}

The survey was conducted by applying a questionnaire to be filled out by the participants under observation. The questionnaire consisted of 20 questions, divided into two sections: socio-demographic features and smoking behaviors. Socio-demographic features consisted of nine questions on age, gender, grade, marital status, background, economic status, and provision of health care. Smoking behaviors included 10 questions about smoking status and initiation, tobacco products use other than cigarettes, quitting attempts, attitudes toward smoking bans and doctors' role model function, and family history.

Owing to the fact that subjects belonged to different grades, data were collected differently for each grade. For the first grade, the classrooms were visited before the lectures started, and data were collected from the attendees after attaining permission from the lecturers.

For the second grade, to ensure to reach as many subjects as possible, the questionnaires were handed out to students and filled out before one of their exams had commenced, with the knowledge and the permission of the doctors supervising over that exam.

For the third grade, the questionnaires were handed out to the students during one of their laboratory classes with the knowledge and permission of the teachers.

For the fourth grade, the classrooms were visited before the lectures started, and data were collected from the attendees after attaining permission from the lecturers.

For the fifth grade, as was the case with the fourth grade, the groups were visited before their classes had commenced, and data were collected from the attendees.

Owing to the fact that the sixth grade in this university is internship, each participant was accessed one by one during their working hours in the hospital to collect the data.

\section{Terms and definitions $(78,79)$}

Tobacco use: Tobacco use is defined as the use of any tobacco product, either smoking or smokeless (78).

Current smoker: A person who smokes cigarettes occasionally or every day.

Previous smoker: A person who used to smoke cigarettes occasionally or everyday but not anymore (smoked >100 cigarettes lifelong but not anymore).

Tried smoking: A person who only tried smoking but did not become a smoker and has not smoked since then.

Lifetime smoker: A person who either tried smoking, who used to smoke but doesn't smoke any more, or who is currently smoking.

Non-smoker: A person who has not and does not smoke (smoked $<100$ cigarettes lifelong).

Water pipe smoker: A person who smokes water pipe (also called shisha, narghile, argila, and hookah).

Cigar smoker: A person who smokes cigars.

Vaporizer smoker: A person who uses vaporizers or e-cigarettes.

Pipe smoker: A person who smokes tobacco pipes. Synonyms: medwakh and dokha.

Quitter: A person who once used to consume tobacco products but has quit for $>12$ months (79).

Countries by income: Classification of countries of origin and the first 12-year residence of the participants was done by using the 
World Bank's new country classification by income 2017-2018 (80). These countries included:

- High-income countries: Cyprus, USA, Austria, Saudi Arabia, England, Qatar, UAE, Kuwait, Oman, Germany, Australia, and Sweden;

- Upper-middle-income countries: Turkey, Libya, Iraq, Lebanon, Algeria, Iran, South Africa, Azerbaijan, Kazakhstan, Brazil, and Saint Kitts and Nevis;

- Lower-middle-income countries: Syria, Jordan, Palestine, Egypt, Nigeria, Sudan, Yemen, Morocco, Kenya, Philippines, Pakistan, Bangladesh, and India;

- Low-income countries: Uganda, Somalia, and Tanzania.

Countries by geographical area: Classification of countries of origin and the first 12-year residence of the participants was done by using the WHO regions classification [81]. These countries included:

- East Mediterranean region: Jordan, Syria, Palestine, Egypt, Iraq, Libya, Oman, Lebanon, Sudan, Pakistan, Yemen, Iran, Saudi Arabia, UAE, Morocco, Qatar, Somalia, and Kuwait;

- European region: Turkey, Cyprus, England, Germany, Austria, Azerbaijan, Kazakhstan, and Sweden;

- African region: Nigeria, Kenya, Algeria, South Africa, Tanzania, and Uganda;

- Americas region: USA, Saint Kitts and Nevis, and Brazil;

- Southeast Asian region: Bangladesh and India;

- Western Pacific region: Philippines and Australia.

\section{Pretest}

A pretest survey was performed on 20 individuals from the lst grade students at the Dentistry School of NEU. The duration of filling out the questionnaire was approximately $15 \mathrm{~min}$, and the questions were observed to be readily understood by the participants.

Permission from the Dean of the Faculty of Medicine was obtained. The study was approved by the Near East University Ethics Committee (for Research Project Evaluation Report with project no. 482, meeting no. 2017/52, dated November 23, 2017 and Project Evaluation Report with project no. 516, meeting no. 2018/54, dated January 18,2018 . Questionnaires were answered anonymously. Informed consent was obtained from the participants. The participants were assured that research results will not be used for any other but educational and scientific purposes.

\section{Data Analysis}

Collected data were analyzed using Statistical Package for the Social Sciences version 18.0.0 software (IBM Corp.; Armonk, NY, USA). Descriptive statistics were expressed as frequencies, mean, median, standard deviations, and maximum and minimum values for analyzed parameters, and marginal and cross tables were made. A p value $<0.05$ was accepted as significant.

\section{Limitations}

Since the native language of the majority of the students was not English, some of the answers might not reflect accurate information but instead what the participant thought the question meant. The results of this research are limited to and representative of the students of the medical school of NEU.

\section{RESULTS}

The results are given under:

I. Socio-demographic features,

2. Smoking habits,

3. Relationship between socio-demographic features and smoking.

\section{Socio-Demographic Features}

Of the I37I medical students, II54 (84.2\%) participated in the study. Some socio-demographic features of the participants are shown in Table I. The age range of the medical students was between 16 and 34 (mean 20.9) years. The female population was $51.1 \%$.

The nationalities and the countries of residence of the participants until age 12 years are shown in Table 2. Turkey has the highest population among countries. Regarding gender, the female population is $53.5 \%$ for citizens of Turkey and $47.4 \%$ for all other countries.

The most frequent nationalities were Turkish by 725 (62.8\%), Northern Cypriot by 112 (9.7\%), Nigerians by 68 (5.9\%), Jordanians by 60 (5.2\%), and Syrians by $58(5.0 \%)$.

The leading countries of residence up to the age of 12 years included Turkey (719 (62.6\%)), Cyprus (II9 (10.4\%)), and Nigeria (68 $(5.9 \%))$

\begin{tabular}{|c|c|c|}
\hline Socio-demographic features & $\mathbf{n}$ & $\%$ \\
\hline \multicolumn{3}{|l|}{ Age (year) $(n=\| 40)$} \\
\hline$\leq 17$ & 20 & 1.8 \\
\hline $18-24$ & 1044 & 91.6 \\
\hline$\geq 25$ & 76 & 6.7 \\
\hline \multicolumn{3}{|c|}{ Mean $\pm S D=20.9 \pm 2.2, \min =16, \max =34$} \\
\hline \multicolumn{3}{|l|}{$\operatorname{Sex}(n=\| 146)$} \\
\hline Male & 560 & 48.9 \\
\hline Female & 586 & 51.1 \\
\hline \multicolumn{3}{|l|}{ Grade $(n=|| 5 \mid)$} \\
\hline $1^{\text {st }}$ & 329 & 28.6 \\
\hline $2^{\text {nd }}$ & 287 & 24.9 \\
\hline $3^{\text {rd }}$ & 300 & 26.1 \\
\hline $4^{\text {th }}$ & $\| 8$ & 10.3 \\
\hline $5^{\text {th }}$ & 84 & 7.3 \\
\hline $6^{\text {th }}$ & 33 & 2.9 \\
\hline \multicolumn{3}{|l|}{ Medical program $(n=\| 154)$} \\
\hline English & 456 & 39.5 \\
\hline Turkish & 698 & 60.5 \\
\hline \multicolumn{3}{|l|}{ Marital status $(n=\| 42)$} \\
\hline Single & 1119 & 98 \\
\hline Married & 12 & 1.1 \\
\hline Relationship & 10 & 0.9 \\
\hline Divorced & । & 0.1 \\
\hline
\end{tabular}


TABLE 2. Nationality and country of residence up to age 12 years for the students in the medical school of NEU (Nicosia, December 2017February 2018) (N=1154)

\begin{tabular}{|c|c|c|c|c|}
\hline & \multicolumn{2}{|c|}{ Nationality } & \multicolumn{2}{|c|}{ Residence until age 12 years } \\
\hline & $\mathrm{n}$ & $\%$ & $\mathbf{n}$ & $\%$ \\
\hline Turkey & 725 & 62.8 & 719 & 62.6 \\
\hline Northern Cyprus & 112 & 9.7 & 119 & 10.4 \\
\hline Nigeria & 68 & 5.9 & 68 & 5.9 \\
\hline Jordan & 60 & 5.2 & 46 & 4.0 \\
\hline Syria & 58 & 5.0 & 26 & 2.3 \\
\hline Palestine & 15 & 1.3 & 10 & 0.9 \\
\hline Egypt & ॥ & 1.0 & 7 & 0.6 \\
\hline Iraq & ॥ & 1.0 & 9 & 0.8 \\
\hline Libya & 10 & 0.9 & 10 & 0.9 \\
\hline Oman & 10 & 0.9 & 12 & 1.0 \\
\hline Lebanon & 9 & 0.8 & 9 & 0.8 \\
\hline USA & 8 & 0.7 & 6 & 0.5 \\
\hline Sudan & 5 & 0.4 & - & 0.0 \\
\hline Pakistan & 5 & 0.4 & - & 0.0 \\
\hline Yemen & 4 & 0.3 & - & 0.0 \\
\hline United Kingdom & 3 & 0.3 & 3 & 0.3 \\
\hline Kenya & 3 & 0.3 & 3 & 0.3 \\
\hline Iran & 3 & 0.3 & 2 & 0.2 \\
\hline Germany & 3 & 0.3 & 4 & 0.3 \\
\hline Bangladesh & 2 & 0.2 & - & 0.0 \\
\hline Morocco & 2 & 0.2 & 1 & 0.1 \\
\hline Saudi Arabia & 2 & 0.2 & 52 & 4.5 \\
\hline United Arab Emirates & - & 0.0 & 19 & 1.7 \\
\hline Austria & 1 & 0.1 & 2 & 0.2 \\
\hline Qatar & - & 0.0 & 7 & 0.6 \\
\hline Kuwait & - & 0.0 & 5 & 0.4 \\
\hline Other & $12^{*}$ & 2.8 & $8^{* *}$ & 0.8 \\
\hline
\end{tabular}

*Algeria, Saint Kitts and Nevis, Philippines, South Africa, Somalia, Azerbaijan, Kazakhstan, Brazil, India, Tanzania, Uganda, and Sweden

**Philippines, South Africa, Uganda, Kazakhstan, India, Tanzania, Sweden, and Australia

The nationalities and the countries of residence according to income and WHO geographical regions grouping of the participants are shown in Table 3.

High-income country nationals were 75 (12.2\%), whereas residence at high-income countries until age 12 years was $35.8 \%$ (162) of the participants. Nationals of upper-middle-income countries were 764 (67.0\%).

The economic status and expenditures for health care of the participants are shown in Table 4.

The economic status of the students was stated as medium by $82.4 \%$. Of the II54 participants, $51.4 \%$ indicated state coverage for health expenditures.
TABLE 3. Nationalities and countries of residence according to the income of the students in the medical school of NEU (Nicosia, December 2017-February 2018) ( $N=1154)$

\begin{tabular}{|c|c|c|c|c|}
\hline & \multicolumn{2}{|c|}{ Nationality } & \multicolumn{2}{|c|}{ Residence } \\
\hline & $\mathrm{n}$ & $\%$ & $\mathbf{n}$ & $\%$ \\
\hline Country according to income & $(n=|| 4 \mid)$ & & $(n=\| 49)$ & \\
\hline High income & 139 & 12.2 & 231 & 20.1 \\
\hline \multicolumn{5}{|l|}{ Upper-middle income } \\
\hline & 764 & 67.0 & 753 & 65.5 \\
\hline \multicolumn{5}{|l|}{ Lower-middle income } \\
\hline Low income & 238 & 20.9 & 165 & 14.4 \\
\hline $\begin{array}{l}\text { Countries according to } \\
\text { geographical regions }\end{array}$ & $(n=\| 49)$ & & $(n=\| 49)$ & \\
\hline Eastern Mediterranean area & 206 & & 215 & 18.7 \\
\hline European area & 846 & & 849 & 73.9 \\
\hline African area & 75 & & 76 & 6.6 \\
\hline Americas area & 10 & & 6 & 0.5 \\
\hline Southeast Asian area & 3 & & 1 & 0.1 \\
\hline Western Pacific area & । & & 2 & 0.2 \\
\hline
\end{tabular}

TABLE 4. Economic status and payment for health care of the students in the medical school of NEU (Nicosia, December 2017-February 2018) $(\mathrm{N}=1154)$

\begin{tabular}{|c|c|c|}
\hline Economic status ( $n=\| 138$ ) & $\mathbf{n}$ & $\%$ \\
\hline Low & 51 & 4.5 \\
\hline Medium & 938 & 82.4 \\
\hline High & 149 & 13.1 \\
\hline Form of payment for health care & $\mathrm{n}$ & \%* \\
\hline State $(n=1116)$ & 574 & 51.4 \\
\hline Out of pocket $(n=1115)$ & 324 & 29.1 \\
\hline Private insurance $(n=|1| 6)$ & 297 & 26.6 \\
\hline
\end{tabular}

The duration of residence in Cyprus for the participants is shown in Table 5.

Of the 824 responder students, $43.4 \%$ (358) had lived in Cyprus for $3-5$ years, and $18.2 \%$ had lived in Cyprus for $>5$ years.

\section{Smoking Habits}

Lifetime cigarette smoking status and current cigarette smoking status of the participants are shown in Table 6.

Students who had never smoked were $41.7 \%$, whereas lifetime smokers were $40.7 \%$, excluding those who only tried. Of the II54 students, 305 (26.5\%) stated that they smoked at least I cigarette/ day, $17.6 \%$ stated that they tried it, $7.0 \%$ stated that they once used to smoke but not anymore, and $7.2 \%$ stated that they smoked $<1$ cigarette/day. Current smokers were $33.7 \%$, and non-smokers were $66.3 \%$.

Cigarette smoking profile (duration, daily number of cigarettes, time of the first cigarette, starting smoking regarding admission to medical school, and medical grade when smoking started) of the participants is shown in Table 7. 
TABLE 5. Duration of residence in Cyprus of the students in the medcal school of NEU (Nicosia, December 2017-February 2018) (N=|154)

\begin{tabular}{|lcc|}
\hline Residence in Cyprus $(\mathbf{n}=\mathbf{8 2 4})$ & $\mathbf{n}$ & $\%$ \\
\hline$<$ year & 26 & 3.2 \\
1-2 years & 290 & 35.2 \\
$3-5$ years & 358 & 43.4 \\
$>5$ years & 150 & 18.2 \\
\hline
\end{tabular}

TABLE 6. Cigarette smoking status of the students in the medical school of NEU (Nicosia, December 2017-February 2018) ( $N=1154)$

\begin{tabular}{lcc|} 
Lifetime cigarette smoking ( $\mathbf{n = I 1 5 2 )}$ & $\mathbf{n}$ & $\%$ \\
\hline$<$ Never & 480 & 41.7 \\
Only tried & 203 & 17.6 \\
Former smoker & 81 & 7.0 \\
At least I cigarette/day & 305 & 26.5 \\
$<$ cigarette/day & 83 & 7.2 \\
Current cigarette smoking (n=|I52) & & \\
Smoker & 388 & 33.7 \\
Non-smoker & 764 & 66.3 \\
\hline
\end{tabular}

TABLE 7. Cigarette smoking profile of smokers among students in the medical school of NEU (Nicosia, December 2017-February 2018) (N=||154)

\begin{tabular}{|c|c|c|}
\hline Duration of cigarette smoking $(n=439)$ & $\mathbf{n}$ & $\%$ \\
\hline$\leq$ year & $\| 4$ & 26.0 \\
\hline $2-5$ years & 237 & 54.0 \\
\hline $6-10$ years & 72 & 16.4 \\
\hline$>10$ years & 16 & 3.6 \\
\hline \multicolumn{3}{|l|}{ No. of cigarettes/day $(n=417)^{*}$} \\
\hline$<1$ & 71 & 17.0 \\
\hline $1-5$ & 86 & 20.6 \\
\hline $6-10$ & 85 & 20.4 \\
\hline $11-15$ & 53 & 12.7 \\
\hline $16-20$ & 75 & 18.0 \\
\hline$>20$ & 47 & 11.3 \\
\hline \multicolumn{3}{|l|}{ Time for the first cigarette $(n=360)$} \\
\hline First 5 min & 70 & 19.4 \\
\hline 6-30 min & 103 & 28.6 \\
\hline$>30 \mathrm{~min}$ & 187 & 52.0 \\
\hline \multicolumn{3}{|l|}{$\begin{array}{l}\text { Time of starting smoking in relation to } \\
\text { admission to the medical school }(n=356)\end{array}$} \\
\hline Before admission to medical school & 194 & 54.5 \\
\hline After admission to medical school & 162 & 45.5 \\
\hline \multicolumn{3}{|l|}{ Grade when smoking started $(n=120)$} \\
\hline$\left.\right|^{\text {st }}$ & 64 & 53.3 \\
\hline $2^{\text {nd }}$ & 40 & 33.3 \\
\hline $3^{\text {rd }}$ & 12 & 10.0 \\
\hline $4^{\text {th }}$ & 3 & 2.5 \\
\hline $5^{\text {th }}$ & 1 & 0.8 \\
\hline sth & - & 0 \\
\hline
\end{tabular}

TABLE 8. Cigarette smoking quit attempt status of the smoker students in the medical school of NEU (Nicosia, December 2017-February 2018) ( $N=379)$

\begin{tabular}{|c|c|c|}
\hline Quit attempt ( $n=379)$ & $\mathbf{n}$ & $\%$ \\
\hline Yes & 187 & 49.3 \\
\hline No & 192 & 50.7 \\
\hline \multicolumn{3}{|l|}{ No. of attempts $(n=133)$} \\
\hline I & 46 & 34.6 \\
\hline 2 & 39 & 29.3 \\
\hline 3 & 22 & 16.6 \\
\hline 4 & 6 & 4.5 \\
\hline 5 & 4 & 3.0 \\
\hline$\geq 6$ & 16 & 12.0 \\
\hline \multicolumn{3}{|l|}{ Quitting attempt method ( $n=92)$} \\
\hline Cold turkey & 65 & 70.6 \\
\hline Reducing gradually & 9 & 9.8 \\
\hline Medications & 5 & 5.4 \\
\hline Switching to e-cigarettes & 3 & 3.3 \\
\hline Snacks, chewing gum, others & 10 & 10.9 \\
\hline \multicolumn{3}{|l|}{ Quitting success ( $n=89$ ) } \\
\hline Yes & 39 & 43.8 \\
\hline No & 50 & 56.2 \\
\hline
\end{tabular}

TABLE 9. Places of exposure to environmental tobacco smoke of the students in the medical school of NEU (Nicosia, December 2017-February 2018) (N=1154)

\begin{tabular}{|lcc|}
\hline Exposure $(\mathbf{n}=\mathbf{I 1 2 8})$ & $\mathbf{n}$ & $\% *$ \\
\hline Cafés and restaurants & 475 & 42.1 \\
When somebody visits & 242 & 21.5 \\
People indoors $(\mathrm{n}=\| 127) * *$ & 322 & 28.6 \\
Visitors at home & 215 & 19.1 \\
At home & 195 & 17.3 \\
\hline *Row percentages over II28 & & \\
**Row percentage over II27 & & \\
\hline
\end{tabular}

Most of the smokers have smoked for $2-5$ years ( $54 \%$ ). Of the 379 smokers, $48.0 \%$ indicated smoking in the first 30 min upon waking up.

Quitting profile (quit attempt, number of attempts, quitting attempt method, and quitting success) of the participants is shown in Table 8.

Of the 379 smokers, $49.3 \%$ attempted quitting at least once. Regarding the method of quitting, $70.6 \%$ of the 92 participants who replied to the question stated quitting cold turkey.

Places of exposure to environmental tobacco smoke according to the participants' statements are shown in Table 9. Exposure to passive smoking is mostly at cafés and restaurants by $42.1 \%$.

Data on the consumption of tobacco products other than cigarettes are shown in Table 10. 
Of the total, 29.3\% (335) of the students use some kind of tobacco product other than cigarettes. Water pipe (hookah) ranks first among these by $21.9 \%$.

TABLE 10. Other tobacco products consumption among students in the medical school of NEU (Nicosia, December 2017-February 2018) $(\mathrm{N}=1154)$

\begin{tabular}{|c|c|c|}
\hline Use of other tobacco products ( $n=\| 45)$ & n & \%* \\
\hline Do not use & 810 & 70.7 \\
\hline Total other tobacco product use & 335 & 29.3 \\
\hline Hookah (n=III3) & 244 & $21.9^{*}$ \\
\hline $\operatorname{Cigar}(n=\| 1 \mid 2)$ & 59 & $5.3^{*}$ \\
\hline Vaporizers or e-cigarettes ( $n=1113$ ) & 29 & $2.6^{*}$ \\
\hline Pipe or medwakh ( $n=|| \mid 2)$ & 27 & $2.4^{*}$ \\
\hline
\end{tabular}

TABLE II. Attitudes of the students in the medical school of NEU to-

ward smoking ban in closed public areas and doctors being role models by not smoking (Nicosia, December 2017-February 2018) (N=|l54)

\begin{tabular}{|lcc|} 
Support for ban in closed public areas $(\mathbf{n}=1093)$ & $\mathbf{n}$ & $\%$ \\
\hline Yes & 942 & 86.2 \\
No & 151 & 13.8 \\
Doctors' role model status $(n=\mid 127)$ & & \\
Yes & 926 & 82.2 \\
No & 201 & 17.8 \\
\hline
\end{tabular}

TABLE 12. Smoking status of family members of the students in the medical school of NEU (Nicosia, December 2017-February 2018) $(\mathrm{N}=1154)$

\begin{tabular}{lcc|}
\hline Smoker member of the family $(\mathbf{n}=\mathbf{8 0 9})$ & $\mathbf{n}$ & $\% *$ \\
\hline Father & 242 & 29.9 \\
Mother & 161 & 19.9 \\
Both parents* & 84 & 10.4 \\
Sibling ( $\mathrm{n}=808)$ & 101 & 12.5 \\
\hline *Row percentages over $n$ & & \\
**Both parents' value includes numbers from the father and mother, and \\
it is not isolated
\end{tabular}

The attitudes of the participants toward smoking ban in closed public areas and doctors being role models for the community by not smoking are shown in Table II.

Of the 1093 students replying to the question, $86.2 \%$ support the ban in closed public places, and $13.8 \%$ do not. Of the 1127 students, $82.2 \%$ approve the role model function of doctors, but $17.8 \%$ do not. Turkish program students are more in favor of bans and doctors being role models ( $89.8 \%$ and $83.7 \%$, respectively).

The smoking status of family members of the participants is shown in Table 12.

Of the II54 Turkish students, 435 (67\%) were informed about the quitline of Turkey (answered by 649 out of 698 Turkish program students).

Relationship between Socio-Demographic Features and Smoking Smoking status according to the gender of the participants is shown in Table 13.

Of the 387 smoker students, $42.1 \%$ and $25.8 \%$ were male and female smokers, respectively. Lifetime smokers were $50.4 \%$ for males, excluding those who only tried in the past. Lifetime smokers were $31.8 \%$ for women, also excluding those who only tried.

Comparison of the smoking status among citizens of Turkey and other country citizens in the medical school of NEU are given in Table 14.

Students who are citizens of the TR smoke by $37.8 \%$, whereas other country citizens' smoking prevalence is $26.6 \%$. TR citizens smoke at significantly higher rates than the other country citizens $(p<0.001)$.

The gender and age status of the participants on catching up the smoking habit in relation to admission to medical school are shown in Table 15.

Of the 355 responder students, $61.2 \%$ of the male smokers had started smoking before admission to medical school, whereas $54.4 \%$ of the female smokers caught up the smoking habit after entering the medical school. The gender difference is significant, meaning more females start smoking during the medical education period than

TABLE 13. Smoking status according to gender among students in the medical school of NEU (Nicosia, December 2017-February 2018) (N=II54)

\begin{tabular}{|c|c|c|c|c|c|c|c|c|}
\hline \multirow[b]{2}{*}{ Smoking status ( $n=\| 45$ ) } & \multicolumn{2}{|c|}{ Male } & \multicolumn{2}{|c|}{ Female } & \multicolumn{2}{|c|}{ Total } & \multirow[b]{2}{*}{$x^{2}$} & \multirow[b]{2}{*}{$p$} \\
\hline & n & $\% *$ & $\mathrm{n}$ & $\% *$ & $\mathbf{n}$ & $\%$ & & \\
\hline Current smoking & $(n=560)$ & & $(n=585)$ & & & & & \\
\hline Non-smoker & 324 & 57.9 & 434 & 74.2 & 758 & 66.2 & & \\
\hline Lifetime smoking & $(n=560)$ & & $(n=585)$ & & & & & \\
\hline Tried & 93 & 16.6 & 109 & 18.6 & & & & \\
\hline Used to smoke & 46 & 8.2 & 35 & 6.0 & & & & \\
\hline At least I cigarette/day & 197 & 35.2 & 107 & 18.3 & & & & \\
\hline$<1$ cigarette/day & 39 & 7.0 & 44 & 7.5 & & & & \\
\hline
\end{tabular}


TABLE 14. Comparison of the smoking status among citizens of Turkey and other country citizens in the medical school of NEU (Nicosia, December 2017-February 2018) (N=1154)

\begin{tabular}{|c|c|c|c|c|c|c|}
\hline \multirow[b]{2}{*}{ Country ( $n=I 152)$} & \multicolumn{2}{|c|}{ Smoker } & \multicolumn{2}{|c|}{ Non-smoker } & \multirow[b]{2}{*}{$x^{2}$} & \multirow[b]{2}{*}{$\mathrm{p}$} \\
\hline & $\mathbf{n}$ & $\%$ & $\mathrm{n}$ & $\%$ & & \\
\hline Turkey & 274 & 37.8 & 450 & 62.2 & & \\
\hline Total & 388 & 33.7 & 764 & 66.3 & & \\
\hline
\end{tabular}

TABLE I5. Time of initiation of smoking regarding entrance to the medical school in relation to gender and age of the smoker students in the medical school of NEU (Nicosia, December 2017-February 2018) (N=388)

\begin{tabular}{|c|c|c|c|c|c|c|}
\hline \multirow{2}{*}{$\begin{array}{l}\text { Initiation } \\
\text { Feature }\end{array}$} & \multicolumn{2}{|c|}{ Before admission } & \multicolumn{2}{|c|}{ After admission } & \multirow[b]{2}{*}{$x^{2}$} & \multirow[b]{2}{*}{$p$} \\
\hline & n & $\%$ & n & $\%$ & & \\
\hline $\operatorname{Sex}(n=355)$ & & & & & 41.2 & $<0.001$ \\
\hline Female & 68 & 45.6 & 81 & 54.4 & & \\
\hline Age group (year) $(n=354)$ & & & & & 13.9 & $p=0.011$ \\
\hline$\geq 25$ & 18 & 40.9 & 26 & 59.1 & & \\
\hline
\end{tabular}

TABLE 16. Smoking status of the students in the medical school of NEU in relation to nationality and countries of residence up until the age of 12 years with country groupings according to income and WHO geographical region (Nicosia, December 2017-February 2018) (N=|154)

\section{Initiation}

Feature

Smoker

Country of origin (nationality) grouped according to income ( $n=\| 40)$

$\begin{array}{lcccc}\text { High } & 36 & 24.0 & 114 & 76.0 \\ \text { Upper-middle } & 284 & 37.8 & 468 & 62.2 \\ \text { Lower-middle and low } & 64 & 27.2 & 171 & 72.8\end{array}$

Country of residence until age 12 years according to income $(n=\| 48)$

$\begin{array}{lcc}\text { High } & 38 & 25.0 \\ \text { Upper-middle } & 311 & 37.4 \\ \text { Lower-middle and low } & 37 & 22.7 \\ \text { Country of origin grouped according to region }(\mathrm{n}=\| 40) \\ \text { East Mediterranean } & 74 & 35.9 \\ \text { Europe } & 304 & 36.0 \\ \text { Africa } & 2 & 2.7 \\ \text { Americas } & 4 & 40.0 \\ \text { Southeast Asia } & - & 0 \\ \text { Western Pacific } & - & 0\end{array}$

Country of residence until age 12 years grouped according to region $(n=\| 48)$

$\begin{array}{lcccc}\text { East Mediterranean } & 77 & 35.8 & 138 & 64.2 \\ \text { Europe } & 301 & 35.5 & 547 & 64.5 \\ \text { Africa } & 2 & 2.6 & 74 & 97.4 \\ \text { Americas } & 5 & 83.3 & 1 & 16.7 \\ \text { Southeast Asia } & - & 0 & 1 & 100 \\ \text { Western Pacific } & 1 & 50.0 & 1 & 50.0\end{array}$

*Row percentages

**Likelihood ratio

\section{Non-smoker}

\%*

$x^{2}$

p

76.0

19.179

$<0.001$

72.8

II4

75.0

21.575

$<0.001$

62.6

77.3

64.1

64.0

97.3

60.0

100

100

64.2

64.5

7.4

6.7

50.0 
TABLE 17. Smoking status of family members of smoker and non-smoker students in the medical school of NEU (Nicosia, December 2017) (N=II54)

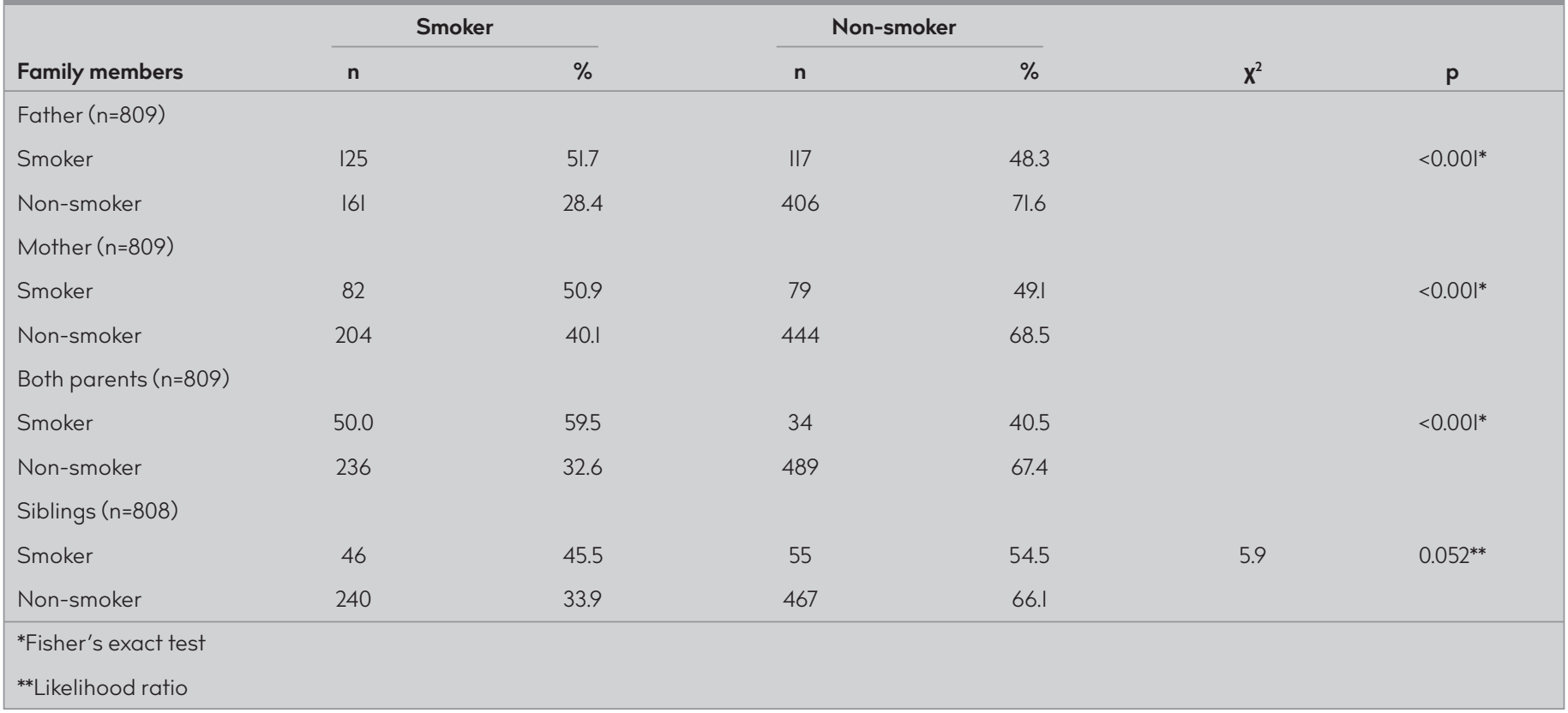

TABLE 18. Other tobacco product use according to cigarette smoking among students in the medical school of NEU (Nicosia, December 2017-February 2018) $(\mathrm{N}=456)$

\begin{tabular}{|c|c|c|c|c|c|c|}
\hline \multirow[b]{2}{*}{ Family members } & \multicolumn{2}{|c|}{ Smoking* } & \multicolumn{2}{|c|}{ Not smoking* } & \multirow[b]{2}{*}{$x^{2}$} & \multirow[b]{2}{*}{$\mathbf{p}$} \\
\hline & $\mathbf{n}$ & $\%$ & $\mathbf{n}$ & $\%$ & & \\
\hline \multicolumn{7}{|c|}{ Other tobacco product consumption $(n=\| 44)$} \\
\hline Yes & 222 & 66.3 & 113 & 33.7 & & $<\left.0.00\right|^{* *}$ \\
\hline No & 162 & 20.0 & 647 & 80.0 & & \\
\hline \multicolumn{7}{|l|}{ Other tobacco product users } \\
\hline Hookah $(n=I I \mid 2)$ & 153 & 62.7 & 91 & 37.3 & & $<\left.0.00\right|^{* *}$ \\
\hline Cigar $(n=I I I)$ & 49 & 83.1 & 10 & 16.9 & & $<\left.0.00\right|^{* *}$ \\
\hline Vaporizers or e-cigarettes (III2) & 21 & 72.4 & 8 & 27.6 & & $<\left.0.00\right|^{* *}$ \\
\hline Pipe or medwakh (III2) & 23 & 85.2 & 4 & 14.8 & & $<\left.0.00\right|^{* *}$ \\
\hline \multicolumn{7}{|c|}{ *Smoking and not smoking are only for cigarette smoking } \\
\hline
\end{tabular}

males. Similarly, the older population group of $\geq 25$ years started smoking more by $59.1 \%$ after entrance to the medical school.

Table 16 shows the smoking status of the students according to their nationalities and countries of residence up until the age of 12 years, countries grouped according to income and WHO geographical region.

In summary, $24.0 \%$ of the citizens of high-income countries, $37.8 \%$ of the citizens of upper-middle-income countries, and $26.9 \%$ of the citizens of lower-middle- and low-income countries were smokers. Smoking was significantly higher among upper-middle-income country citizens $\left(\chi^{2}=19.2, p<0.001\right)$. The smoking rate was similar (36.7\%) for upper-middle-income country citizens in the English program of NEU Medical School as well; thus, the high rate is not due to TR citizens only.

Regarding the regional distribution of countries of origin and residence until the age of 12 years, smoking rates were lowest among citizens of African countries. Of European country citi- zens in the English program of the medical school, $41.5 \%$ were smokers, ranking first among country regions, similar to the results of the total group with $36 \%$.

The status of the smoking features of family members in relation to the smoking of students is shown in Table 17.

Smoking of the mother and/or the father is closely related to the smoking status of the child. The offsprings of smoker parents smoke at significantly higher rates than those of non-smoking parents $(p<0.001)$.

The use of tobacco products other than cigarettes in relation to the smoking status of the participants is shown in Table 18.

The use of other tobacco products is closely related to smoking cigarettes. Cigarette smokers use all other tobacco products at significantly higher levels than non-smokers. However, 37.3\% (9l students) of hookah users are not cigarette smokers. 
TABLE 19. The comparison of the smoking and non-smoking students in the medical school of NEU regarding their attitudes toward banning smoking in closed public areas and toward doctors being role models for the community (Nicosia, December 2017-February 2018) ( $N=1154$ )

\begin{tabular}{|c|c|c|c|c|c|c|}
\hline \multirow[b]{2}{*}{ Family members } & \multicolumn{2}{|c|}{ Smoker } & \multicolumn{2}{|c|}{ Non-smoker } & \multirow[b]{2}{*}{$x^{2}$} & \multirow[b]{2}{*}{ p } \\
\hline & $\mathbf{n}$ & $\% *$ & n & \%* & & \\
\hline \multicolumn{7}{|c|}{ Positive attitude toward ban in closed areas $(n=1092)$} \\
\hline No & 77 & 21.2 & 74 & 10.2 & & \\
\hline \multicolumn{7}{|c|}{ Positive attitude toward role model function of doctors ( $n=\| 26$ ) } \\
\hline No & 124 & 33.3 & 76 & 10.1 & & \\
\hline \multicolumn{7}{|c|}{${ }^{*}$ Column percentage } \\
\hline **Fisher's exact te & & & & & & \\
\hline
\end{tabular}

TABLE 20. The gender distribution of the attitudes of the participants of the medical school of NEU regarding doctors' status as non-smoking role models (Nicosia, December 2017-February 2018) (N=|l54)

\begin{tabular}{|c|c|c|c|c|c|}
\hline & \multicolumn{4}{|c|}{ Role model function } & \multirow[b]{3}{*}{$\%^{2} p$} \\
\hline & \multicolumn{2}{|c|}{ Yes } & \multicolumn{2}{|c|}{ No } & \\
\hline & n & \%* & $\mathbf{n}$ & $\% *$ & \\
\hline \multicolumn{6}{|c|}{ Gender $(n=\| 20)$} \\
\hline Male & 423 & 78.2 & 118 & 21.8 & \multirow[t]{2}{*}{$0.001^{* *}$} \\
\hline Female & 497 & 85.8 & 82 & 14.2 & \\
\hline *Row pe & & & & & \\
\hline
\end{tabular}

TABLE 21. Smoking status of the participants according to the grade in the medical school of NEU (Nicosia, December 2017-February 2018) $(\mathrm{N}=1154)$

\begin{tabular}{|c|c|c|c|c|}
\hline & \multicolumn{4}{|c|}{ Smoking status } \\
\hline & \multicolumn{2}{|c|}{ Non-smoker } & \multicolumn{2}{|c|}{ Smoker } \\
\hline & $\mathrm{n}$ & $\%$ & $n$ & $\%$ \\
\hline \multicolumn{5}{|c|}{ Grade $(n=\| 49)$} \\
\hline $1^{\text {st }}$ & 237 & 72.5 & 90 & 27.5 \\
\hline $2^{\text {nd }}$ & 170 & 59.2 & 117 & 40.8 \\
\hline $3^{\text {rd }}$ & 195 & 65.0 & 105 & 35.0 \\
\hline $4^{\text {th }}$ & 77 & 65.3 & 41 & 34.7 \\
\hline $5^{\text {th }}$ & 58 & 69.0 & 26 & 31.0 \\
\hline $6^{\text {th }}$ & 25 & 75.8 & 8 & 24.2 \\
\hline Total & 762 & 66.3 & 387 & 33.7 \\
\hline
\end{tabular}

The attitudes of smoker and non-smoker participants regarding smoking ban in closed public areas and doctors being role models for the community are shown in Table 19.

Smoker students who supported the ban on smoking in closed areas were $78.8 \%$, whereas non-smoker students who supported the ban were $89.8 \%$. Non-smokers who supported banning smoking in closed public areas are more than smokers who supported the ban; the difference is statistically significant $(p<0.001)$. Similarly, $66.7 \%$ of smokers and $89.9 \%$ of non-smokers stated that doctors should be role models by not smoking. This difference is also statistically significant $(p<0.001)$.
TABLE 22. The attitudes regarding doctors being role models by not

smoking of the participants according to the grade in the medical

school of NEU (Nicosia, December 2017-February 2018) (N=II54)

\begin{tabular}{|c|c|c|c|c|}
\hline & \multicolumn{4}{|c|}{ Role model function } \\
\hline & \multicolumn{2}{|c|}{ Yes } & \multicolumn{2}{|c|}{ No } \\
\hline & $\mathrm{n}$ & $\%$ & $\mathbf{n}$ & $\%$ \\
\hline \multicolumn{5}{|c|}{ Grade (n=II24) } \\
\hline lst $^{\text {st }}$ & 270 & 82.8 & 56 & 17.2 \\
\hline $2^{\text {nd }}$ & 234 & 85.1 & $4 \mid$ & 14.9 \\
\hline $3^{\text {rd }}$ & 232 & 80.6 & 56 & 19.4 \\
\hline $4^{\text {th }}$ & IOI & 85.6 & 17 & 14.4 \\
\hline $5^{\text {th }}$ & 68 & 81.0 & 16 & 19.0 \\
\hline $6^{\text {th }}$ & 19 & 57.6 & 14 & 42.4 \\
\hline
\end{tabular}

The gender distribution of the attitudes of the participants regarding doctors' status as non-smoking role models is shown in Table 20.

Male students who think that doctors should be role models for the community by not smoking were $78.2 \%$, whereas $85.8 \%$ of females shared this view. The difference between the two genders was statistically significant $(p=0.00 I)$.

Table 2 I shows the smoking status of the participants according to the grade of medical school.

The attitudes regarding doctors being role models by not smoking of the participants according to the grade in the medical school of NEU are shown in Table 22.

The low percentage of positive attitudes in the 6th grade does not comply with the smoking status of these students, the smoking rate being lowest by $24.2 \%$ among the 6 th-year students.

The attitudes toward smoking ban in closed public areas of the participants according to gender are shown in Table 23. There is no significant gender difference regarding this issue.

The attitudes toward smoking ban in closed public areas of the participants according to their grade are shown in Table 24. 
The attitudes of the participants regarding doctors being role models by not smoking according to their nationalities and country of residence until age 12 years are shown in Table 25. Countries are grouped according to income [79].

Of the students from high-income countries, $79.0 \%$ agree that doctors should be role models by not smoking, as do the $81.1 \%$ from upper-middle-income countries and $87.4 \%$ from lower-middle- and low-income countries. The differences among the groups are not statistically significant according to the nationality of the students.

Comparison of the gender status regarding Turkish students and other country citizens in the medical school are presented in Table 26.

\begin{tabular}{|c|c|c|c|c|}
\hline & \multicolumn{4}{|c|}{ Ban support } \\
\hline & \multicolumn{2}{|c|}{ Yes } & \multicolumn{2}{|c|}{ No } \\
\hline & $\mathbf{n}$ & $\%$ & $\mathbf{n}$ & $\%$ \\
\hline \multicolumn{5}{|c|}{ Gender $(n=1086)$} \\
\hline Male44I & 84.3 & 82 & 15.7 & $0.095^{*}$ \\
\hline Female & 495 & 87.9 & 68 & 12.1 \\
\hline
\end{tabular}

TABLE 24. Attitudes of the students toward smoking ban in closed public areas according to their grades in the medical school of NEU (Nicosia, December 2017) (N=|154)

\begin{tabular}{|c|c|c|c|c|c|}
\hline & \multicolumn{4}{|c|}{ Ban support } & \multirow[b]{3}{*}{$x^{2} p$} \\
\hline & \multicolumn{2}{|c|}{ Yes } & \multicolumn{2}{|c|}{ No } & \\
\hline & $\mathrm{n}$ & $\%$ & $\mathbf{n}$ & $\%$ & \\
\hline \multicolumn{6}{|c|}{ Grade $(n=1090)$} \\
\hline$\left.\right|^{\text {st }}$ & 263 & 83.8 & 51 & 16.2 & \multirow[t]{6}{*}{8.030 .16} \\
\hline $2^{\text {nd }}$ & 222 & 83.5 & 44 & 16.5 & \\
\hline $3^{\text {rd }}$ & 256 & 90.1 & 28 & 9.9 & \\
\hline $4^{\text {th }}$ & 100 & 87.0 & 15 & 13.0 & \\
\hline $5^{\text {th }}$ & 72 & 90.0 & 8 & 10.0 & \\
\hline $6^{\text {th }}$ & 27 & 87.1 & 4 & 12.9 & \\
\hline
\end{tabular}

Female students comprise $53.5 \%$ of Turkish students, whereas females are $47.2 \%$ of other country students.

Smoking status of the Turkish citizens according to gender is shown in Table 27.

Of the II54 Turkish students, $45.2 \%$ of males and $31.4 \%$ of females are smokers. Smoking frequency is higher among Turkish students than the overall frequencies that are $42.1 \%$ for males and $25.8 \%$ for females.

\section{DISCUSSION}

The smoking and other tobacco product consumption features of the medical students studying in the NEU School of Medicine were studied in this cross-sectional study. Of a total of I37I medical students, II54 (84.2\%) responded to the questionnaire.

In the present study, students who never have smoked were $41.7 \%$, whereas lifetime smokers were $40.7 \%$, excluding those who only tried. Of the II54 students, 305 (26.5\%) stated that they smoked at least I cigarette/day, $17.6 \%$ stated that they tried it, $7.0 \%$ indicated once smoking but not anymore, and $7.2 \%$ stated smoking < l cigarette/day. The total of daily and occasional (current) smokers was 33.7\%, and non-smokers were $66.3 \%$.

In a joint study of USA Brown University and Italian Bologna University medical schools, the smoking prevalence was $29.5 \%$ in Bologna University, which is lower but close to our results, whereas it was much lower in Brown University with 6.1\% (82).

According to a systematic review in 2007, the lowest prevalences with $2 \%-4 \%$ were found among medical students of America, Australia, China, and India during the late 1990s. In various studies, prevalences were $<10 \%$ in these countries and also in Thailand and Malaysia. On the other hand, high smoking rates were prevalent among male medical students in Greece (41\%) and Spain (42\%) (4).

In a cross-sectional study conducted in 2009 among medical students of 12 European countries, including Germany, Italy, Poland, and Spain, the mean smoking prevalence was $29.3 \%$, with the lowest rate in Germany with $28.0 \%$ and the highest rate in Italy with $31.3 \%$ (83). These countries are those with higher

TABLE 25. The attitudes of the participants regarding doctors being role models by not smoking according to their nationalities and residence until age 12 years in the medical school of NEU (Nicosia, December 2017-February 2018) (N=II54)

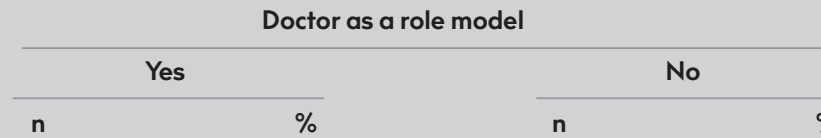

\begin{tabular}{|c|c|c|c|c|c|c|}
\hline \multicolumn{7}{|c|}{ Countries of origin according to income $(n=1116)$} \\
\hline Upper-middle & 607 & 81.1 & $|4|$ & 18.9 & & \\
\hline \multicolumn{7}{|c|}{ Countries of residence until age 12 years according to income $(n=|| 24)$} \\
\hline Upper-middle & 606 & 82.2 & |3| & 17.8 & & \\
\hline Lower-middle and low & 140 & 88.6 & 18 & 11.4 & & \\
\hline
\end{tabular}


TABLE 26. Comparison of gender status regarding Turkish students

and other country citizens in the medical school of NEU (Nicosia,

December 2017-February 2018) (N=|154)

\begin{tabular}{|lccc|} 
& \multicolumn{2}{c}{ Gender } & \\
\cline { 2 - 3 } & Male \% & Female \% & Total \\
\hline Citizens of all other countries & 22452.8 & 20047.2 & 424 \\
Citizens of Turkey & 33646.5 & 38653.5 & 722 \\
Total & 56048.9 & 58651.1 & 1146 \\
\hline
\end{tabular}

prevalences of smoking in Europe, and the higher prevalences among medical students are a reflection of the general population. A study from Egypt has shown similar characteristics with our study regarding non-smokers comprising the majority, but $46.7 \%$ had smoked for some time in their lives, and 35\% were current tobacco users (84).

Smoking the first cigarette in the first 30 min upon waking up is one of the indicators of nicotine dependency. According to this criterion, $48 \%$ of the smokers were physiologically nicotine dependent in our study. Of the smokers in our study, 51.0\% adopted the smoking habit before entrance to the medical school, and $49.0 \%$ acquired the smoking habit after starting the medical education. Of those who started smoking at the medical school, the majority (57.0\%) stated that they started smoking during the first year of their medical education. None of the students had started smoking at the 5 th or 6th grades.

Approximately half of the smokers in our study had attempted quitting smoking in the past, the majority tried to quit without assistance, and $63.5 \%$ of these were successful. In a study of 12 European countries, the medical students were found to be informed about the nicotine preparations and some anti-depression drugs used for quitting smoking (83).

The majority of the participants of the current study have indicated not consuming tobacco products other than cigarettes. Some students (23.3\%) consume water pipe, and a minority consumes other tobacco products. There are some students who consume only water pipe (9\%) without smoking cigarettes who may be considered potential cigarette smokers.

Most of the participants announced the cafés and restaurants as places of exposure to second-hand smoke. These findings indicate the violation of the legal measures in force in Northern Cyprus, specifically in cafés and restaurants. Regarding this issue, most of the students were found to be in positive attitudes toward smoking bans and doctors being role models by not smoking, which is in compliance with other country studies ( 81 , $83,84)$. American students were more in favor of the role model function of doctors (93.9\%) than Italian students (74.7\%) (84).

Therefore, medical students worldwide mostly share the opinion that doctors should be role models for the community by not smoking. The fact that there are some exceptions to this finding is an indicator of the insufficiency of medical education. The attitudes of medical students on the role model function of doctors and support of smoking bans are actually expected to be $100 \%$ positive. Students with negative attitudes in this respect were $10 \%-16 \%$ in our study.
TABLE 27. Smoking status of the Turkish citizens according to gender

in the medical school of NEU (Nicosia, December 2017-February

2018) $(\mathrm{N}=725)$

\begin{tabular}{|lccc|} 
& \multicolumn{2}{c}{ Smoking status } & \\
\cline { 2 - 3 } Gender & Non-smoker $\%$ & Smoker $\%$ & Total \\
\hline Male & 18454.8 & 15245.2 & 336 \\
Female & 26368.3 & 12231.4 & 385 \\
Total & 44762.0 & 27438.0 & 721 \\
\hline
\end{tabular}

The progress in tobacco control and the evidence mounting on the health consequences of smoking showed dramatic declines in the prevalences of smoking doctors, especially in high-income countries. Medical doctors smoke less than dentists and nurses. The lowest smoking prevalences for physicians are seen in the USA, Australia, and the United Kingdom. Similarly, the smoking prevalences of Japanese doctors decreased dramatically from $66.0 \%$ to $7.0 \%$ during 1965-2009, with higher decline rates for males (85). The doctors of the developing world continue to smoke at high rates in developing countries, similar to their native people (3).

Our study has found that male students smoke at statistically higher frequencies than female students, with a rate of $43.5 \%$ for males and $28.1 \%$ for females. The highest prevalences were among Turkish citizens for both males and females. Similarly, a study of 12 European countries revealed higher smoking frequencies for males in Germany, Italy, and Spain as well, but the smoking prevalence of Polish female medical students was higher than that of Polish male students (83). In some studies, the smoking prevalences of female medical students are found to be very low, approaching zero in some countries because of cultural reasons (4). On the other hand, female students in the current study indicated that they started smoking during their medical education period at significantly higher levels than male students.

The smoking status of parents and other family members was found to be influential on the smoking status of students in the current study. The students whose fathers are non-smokers smoke significantly less than those whose fathers are smokers. There is a similar association for mothers and students as well in our study. Other studies reveal similar findings regarding family members; if the parents or siblings smoke, there is a four-fold increase in the prevalence of smoking of individuals compared with those whose parents or siblings do not smoke $(42,43)$.

Non-smokers and female students in the current study are in support of smoking bans at significantly higher levels than smokers and male students. There is a general support for smoking bans among medical students according to various research findings (86).

Most of the medical students share the opinion that doctors should be non-smoking role models, whether they are smokers or non-smokers themselves. However, non-smokers and female students are in a positive attitude at significantly higher frequencies in this respect, similar to other country studies $(82,84)$.

Global studies have also investigated the status of medical education curricula regarding the tobacco issue. A study from Cairo 
revealed that only $34.2 \%$ of the medical students indicated having training on cessation treatment (84). The European study found that only $16.5 \%$ of the students had had tobacco cessation treatment education (83). Contrary to this research, the medical program of the students in the USA-Italy study indicated high levels of tobacco education with $95.2 \%$ of the students for USA and $76.4 \%$ of the students for Italy (82).

The current cross-sectional study evaluated the smoking behaviors of the students of a medical school in the TRNC. The smoking prevalence was high especially for the male students (42\%) compared with the female students (23\%), with an overall prevalence of $33 \%$. Of the smokers, $50 \%$ had nicotine addiction. The lifetime smoking frequency was high with $48 \%$, although lower than in a 2014 study conducted in six universities of the TRNC that found lifetime cigarette smoking among students from all faculties to be $69.5 \%$ (I7).

Male students were found to smoke more than female students with the lifetime smoker frequency being $60 \%$ for male students compared with $36 \%$ for female students. The large difference between the lifetime smoker and current smoker frequencies among both male and female students is mainly due to the students who tried but fortunately did not pick up the smoking habit. The finding that male students smoke more than female students is consistent with other studies' findings (87).

Since our study included medical students in the English language program, it was possible to evaluate the variations in the smoking status among students of different nationalities. The countries were categorized according to the World Bank country income groups regarding the countries of origin and the countries lived in until the age of 12 years. Students from upper-middle-income countries smoked the most, followed by students from high-income countries, with the lowest frequency for low- and lower-middle-income countries combined. Students who lived in high-income countries until the age of 12 years smoke the most with a rate of $40 \%$. Growing up in highand upper-middle-income countries appears to be associated with a stronger chance to become a smoker. Similarly, the WHO data by the World Bank income group reveals that the smoking rates for male adults are highest in upper-middle-income countries with $43 \%$ and highest in high-income countries for female adults with $18 \%$ (88). It appears that the richer the country the students were living in, the higher the chance for them to be smokers.

On the other hand, a recent meta-analysis in 2016 found that cigarette smoking was significantly associated with lower income worldwide, suggesting a change in smoking trends according to income (89). Lower socio-economic status is related with increased smoking rates, which is probably due to less education levels (90). Even though our findings are consistent with the WHO data by the World Bank income group (88), the results of our students may not be reflective of the smoking status of other students in their native countries. NEU is a private university, and most students come from higher socio-economic families affected less by the costs of smoking (9l). However, smoking people of lower socio-economic status are more responsive to changes in cigarette prices and less to health publicity (92).
Country-specific smoking prevalences according to the top five nationalities revealed high frequencies for Jordanians with $50 \%$ and Turkish with 44\%, followed by Syrians with 35\% and TRNC citizens with 33\%. Smoking frequency was low for Nigerian students (1.5\%) and the African region in general (3\%). However, the overall smoking status in our study was higher than that in previous international research for medical students.

In Nigeria, one study on university students revealed lifetime use of tobacco to be $10.5 \%$ (22) and another study in a different university to be $9.6 \%$ (23), which is relatively low but higher than the results of our Nigerian group, which may be reflecting the influence of medical education.

A 2007 study on cigarette smoking in Syria on medical students found the prevalence to be II\% (25\%), way lower than our result of $35 \%$ for Syrians. On the other hand, a study among medical students of a university in Amman, Jordan revealed the prevalences to be $26 \%$ among male and $7 \%$ among female students (28). The results of Jordanian students in our study are also higher than those in the literature available, which might be due to the fact that Jordanian students studying in NEU have higher income levels than most students in Jordan. These findings indicate that the mean frequencies of smoking among students in the Middle East countries remain relatively high.

Even though higher education should according to literature decrease smoking prevalences $(93,94)$, our results have shown considerable smoking onset after admission to medical school. Of the smokers in our study, 59\% started smoking before entering the medical school, whereas $41 \%$ started after admission. More men picked up smoking before the medical education period than women, and the difference between the sex groups was statistically significant.

Contrary to other research, a study from China found that medical students have higher rates of smoking than other students, but most of the smokers were found to be occasional smokers (95). On the other hand, a study in Greece revealed that the smoking rate of medical students was 35\%, whereas it was $50 \%$ for other students (96). These results were statistically significant, but male medical students in the 4th grade and above smoked more than students from other schools $(96,97)$.

The association of the status of tobacco dependence and interventions through education and other programs has been investigated in a number of national and global studies. Current tobacco use was lower among public college students who had attended high school in Massachusetts and who had been exposed to the Massachusetts Tobacco Cessation and Prevention Program (MTCP) during high school than those who had attended high school in another state ( $31.5 \%$ vs. $42.6 \%, p=0.006$ ), which persisted after the necessary adjustments. The MTCP may have reduced tobacco use among this group of young adults (98). This may also be relevant for the influence of medical education on medical students.

A cohort study conducted in Turkey in 2006 to monitor the incidence of smoking during the medical education period found that $30 \%$ of non-smoking students at registration have become smokers by the time they reached the final grade, and that 
most new incidences occurred during the first three grades (29), which is similar to our study. This suggests that the university education period in general might be an influential factor for the adoption of the smoking habit, and that medical education is insufficient for raising awareness among students toward the hazards of smoking and preventing new incidences. Additional$l y$, the attitudes of medical students toward anti-smoking efforts are not $100 \%$ positive (30) as was also true for our study. Medical students are subject to the same factors that lead their equals into smoking, such as peer influence, smoking family members, stress, and depression (3l).

\section{Tobacco Control and Medical Education}

Data on medical students imply the inadequacy of the medical education in both prevention and also ending the smoking habit among medical students. Thus, there is a necessity for assessing the status of medical education and curricula regarding the tobacco issue worldwide.

An international survey searched for tobacco education in medical schools on a country basis (99). The survey investigated medical schools from 109 countries with a response rate of $32 \%$ from medical schools and $64 \%$ from countries. Of the respondent 665 medical schools, 39\% were from developed, and 28\% were from less developed countries. Of the 561 medical schools responding to questions on teaching options, $27 \%$ indicated teaching a specific module on tobacco, $77 \%$ integrated tobacco education with other topics, $31 \%$ included tobacco information in some subjects related to the tobacco issue, and $4 \%$ did not teach about tobacco at all. The most common topics in the programs were health consequences of tobacco use $(94 \%)$, health effects of passive smoking (84.5\%), epidemiology of tobacco use $(81 \%)$, nicotine dependence $(78 \%)$, and taking a smoking history $(75 \%)$. The most popular methods were lectures, case study discussions, problem-based learning exercises, and patient-centered approaches, such as role plays. The present study showed a progress of tobacco education in medical schools over the previous 10 years worldwide $(57,58)$, although far from being sufficient, taking into account the non-respondent schools that probably have less or no tobacco education in their curricula $(99,100)$.

In a survey of fourth-year medical students at some schools in New York City, the medical students were found as aware of the harms of smoking, but $64 \%$ of the students stated their capability to assist patients in cessation and treating nicotine addiction as inadequate (IOI).

Another study in the USA investigated the first- and third-year medical students of 10 medical schools regarding extensive tobacco education. The tobacco education in these schools included a web-based course, a role-play classroom demonstration, and a clerkship booster session, which was found as more efficient than classic training hours $(102,103)$.

Learning is optimal when knowledge and experience is taught early, reinforced consistently, and integrated through all aspects of a curriculum (103). Early education on tobacco dependence treatment skills using "didactics, preceptor modeling, patient observation, instruction with receipt of feedback, behavioral counseling" may be helpful tools for medical students. A stand- ardized tobacco education is needed for the medical education process at a global perspective (104).

The first program integrating tobacco control across all years of medical education in a low- or middle-income country was reported from India. The development, pretesting, and piloting of an innovative modular tobacco curriculum have been presented in 2015 by Yamini at al. (105). Fifteen modules were developed focusing on the impact of tobacco control on public health, tobacco hazards for specific organ systems, diseases related to smoking and chewing tobacco, and the influence of tobacco on medication effectiveness. Training videos on cessation were prepared on specific diseases (105).

Similarly, a tobacco control and cessation program has been introduced and implemented for the past 3 years (2015-2018) in the public health committee of NEU medical education curriculum. The program starts in the first year, continuing in the third year, and ending up with the internship program in the sixth year. The tobacco control program consists of all aspects of comprehensive tobacco control and interventions with special emphasis on tobacco cessation. The first year program consists of lectures on health consequences of tobacco use and doctors' role in cessation and tobacco control. The third-year tobacco education is a multidimensional program on all aspects of comprehensive tobacco control and treatment of nicotine addiction, consisting of lectures and class practices. During the sixth year, the internship program includes a student-centered interactive module on tobacco control and smoking cessation with practical aspects to develop the skills of the students to assist their patients to quit smoking.

The methods of the tobacco control program include mainly lectures, group studies, case study discussions, behavioral counseling exercises, and role plays on cessation, health education, and promotion. Although the attitudes of the students regarding the tobacco issue are positive, their behaviors have not changed much as is shown by the high prevalence of smokers in the study.

The results of the present study and continuous monitoring afterwards may highlight the efficacy of tobacco education in the prevention of smoking among medical students of NEU in the future and may help developing new programs for this end. The inclusion of medical students themselves in the tobacco control activities in the university, including smoke-free campuses, may facilitate the decline of the smoking prevalence among medical and other students in the university.

Our study has limitations. Since the native language of the majority of the students is not English, some of the answers might not reflect accurate information but instead their perception of the questions. The results of this research are limited to and representative of the students of the medical school of NEU.

\section{CONCLUSION}

The smoking prevalence among medical students in the current study was high. The overall smoking status in our study was higher than that in most of the previous international research for medical students. 
More than half of the male students had started smoking before their medical education era. On the other hand, more than half of the female students indicated starting smoking after entrance to the medical school. The results regarding female students reveal the significance of the early initiation of tobacco control education in the medical schools.

Water pipe is the second most common tobacco product consumed by the students. Sixty students were consumers of water pipe but not cigarettes, indicating a risk of future cigarette smoking addiction.

The findings of the present study point out the need of more consistent and comprehensive tobacco control education in the medical schools, as is also emphasized in the current literature. The education on tobacco should include knowledge, attitude, and behavioral aspects, including personal and community approaches, as well as skills for the cessation of smoking. The medical curricula should be revised according to the needs of the tobacco issue as a public health problem.

The medical students should be trained in all aspects of the tobacco control measures, such as community education with media campaigns, preventing passive smoking, developing policies for decision makers, and also offering help to smokers who want to quit. They should be trained in special centers working on the issue in the health system with special emphasis on their role model function and taking a tobacco use history from all patients. The inclusion of medical students themselves in the tobacco control activities is an important step for promoting tobacco control activities in university campuses.

Tobacco products sales should be banned by administrative and legislative measures in all health premises, as well as university campuses, which should all be smoke-free areas. Cessation programs and pharmacological therapies should be available and free to everyone who needs them. These comprehensive measures as a whole will provide the key to the achievement of worldwide non-smoking medical students and doctors.

For successfully developing all these programs and taking the necessary measures, a close cooperation and joint action of the public health authority and the universities are mandatory.

Tobacco issue is an important topic of public health, and the role of medical doctors in smoking cessation and tobacco control is well documented.

Medical education is crucial for well-resourced future doctors on the issue. Nevertheless, it is reported by international research that there is a gap in the medical curricula regarding tobacco control and cessation programs. The starting point for developing medical curricula is the recording of the current status of tobacco use among students worldwide to initiate innovative tobacco education programs.

There were no previous recorded data in the TRNC on the smoking status of exclusively the medical students. Thus, as a starting point, we have decided to document the status of the medical students on their tobacco use knowledge, attitudes, and behaviors, as a representative study of our medical school.
The intension is monitoring the changes in years of the relevant features of the medical students after the inclusion and consistent implementation of the new tobacco education program introduced into the medical curricula to contribute to global medical education and tobacco control.

Ethics Committee Approval: Ethics committee approval was received for this study from Near East University Ethics Committee.

Informed Consent: Informed consent was obtained from the patients who participated in this study.

Conflict of Interest: The author have no conflicts of interest to declare.

Financial Disclosure: The author declared that this study has received no financial support.

\section{REFERENCES}

I. World Health Organization. WHO report on the global tobacco epidemic 2017. Available from: http://www.who.int/tobacco/global_report/2017/en/. (Cited 2017 December 4)

2. Law M, Tang JL. An analysis of the effectiveness of interventions intended to help people stop smoking. Arch Intern Med 1995; 155: 1933-4I. [CrossRef]

3. Smith DR, Leggat PA. An international review of tobacco smoking in the medical profession: 1974-2004. BMC Public Health 2007; 7: II5. [CrossRef]

4. Smith DR, Leggat PA. An international review of tobacco smoking among medical students. Journal of postgraduate medicine 2007; 53: 55. [CrossRef]

5. Centers for Disease Control and Prevention (CDC). Physician and other health-care professional counseling of smokers to quit - United States, 1991. MMWR Morb Mortal Wkly Rep 1993: 42: 854-7.

6. The Health Consequences of Smoking. A Report of the Surgeon General. Office of the Surgeon General (US). Atlanta (GA): Centers for Disease Control and Prevention (US); 2004. Available from: https://www.ncbi.nlm.nih.gov/books/NBK44695. (Cited 2018 February 20)

7. Schmitz N, Kruse J, Kugler J. Disabilities, quality of life, and mental disorders associated with smoking and nicotine dependence. Am J Psychiatry 2003; 160: 1670-6. [CrossRef]

8. US Department of Health and Human Services. The Health Consequences of Smoking-50 Years of Progress: A Report of the Surgeon General. Atlanta: U.S. Department of Health and Human Services, Centers for Disease Control and Prevention, 2014. Available from: https://www.ncbi.nlm.nih.gov/pmc/articles/PMC3908632/. (Cited 2017 December 10)

9. US Department of Health and Human Services. How tobacco smoke causes disease: The Biologic and Behavioral Basis for Smoking Attributable Disease. Atlanta: US Department of Health and Human Services, CDC, Office on Smoking and Health, 2010. Available from: https://www.cdc.gov/tobacco/data_statistics/ sgr/2010/consumer.../consumer.pdf.

10. National Cancer Institute. Harms of Cigarette Smoking and Health Benefits of Quitting. 2017. Available from: https://www.cancer. gov/about-cancer/causes-prevention/risk/tobacco/cessation-fact-sheet. (Cited 2017 December 5)

II. Martin, T. 599 Ingredients and additives in cigarettes. Available from: https://www.verywell.com/big-tobaccos-list-of-599-cigarette-additives-2824422. (Cited 2018 February 26)

12. Boutrel B, Koob GF. What keeps us awake: The neuro-pharmacology of stimulants and wakefulness promoting medications. Sleep 2004; 27: II8I-94. [CrossRef]

13. Pomerleau OF. Nicotine and the central nervous system: biobehavioral effects of cigarette smoking. AJM 1992; 93: 2-7. [CrossRef]

14. Fowler G. Educating doctors in smoking cessation. Tob Control 1993; 2: 5-6. [CrossRef] 
15. Nett LM. The physician's role in smoking cessation: A present and future agenda. Chest 1990; 97(Suppl 2): 28S-32S. [CrossRef]

16. Garfinkel L. Cigarette smoking among physicians and other health professionals, 1959-1972. CA Cancer J Clin 1976; 26: 373-5. [CrossRef]

17. Cakici E, Cakici M, Es A, Ergun D. The prevalence and risk factors of substance use among university students in Turkish Republic of Northern Cyprus. Anadolu Psikiyatri Derg 2014; 15: 108-15. [CrossRef]

18. Akvardar Y, Demiral Y, Ergor G, Ergor A. Substance use among medical students and physicians in a medical school in Turkey. Social psychiatry and psychiatric epidemiology 2004; 39: 502-6. [CrossRef]

19. Metintaș S, Sariboyaci MA, Nuhoğlu S, Metintaș M, Kalyoncu C, Etiz $\mathrm{S}$, et al. Smoking patterns of university students in Eskisehir, Turkey. Public health 1998; 112: 261-4. [CrossRef]

20. Guleç M, Bakir B, Ozer M, Ucar M, Kilic S, Hasde M. Association between cigarette smoking and depressive symptoms among military medical students in Turkey. Psychiatry Res 2005; 134: 281-6. [CrossRef]

21. Ogus C, Ozdemir T, Kara A, Senol Y, Cilli A. Smoking habits of grade I and VI medical students at Akdeniz University Medical Faculty. Turkiye Klinikleri Arch Lung 2004; 5: 139-42. 22. Makanjuola AB, Daramola TO, Obembe AO. Psychoactive substance use among medical students in a Nigerian university. World Psychiatry 2007; 6: I12.

23. Dania MG, Ozoh OB, Bandele EO. Smoking habits, awareness of risks, and attitude towards tobacco control policies among medical students in Lagos, Nigeria. Annalsafrmed 2015; 14: I-7. [CrossRef]

24. Maziak W, Hammal F, Rastam S, Asfar T, Eissenberg T, Bachir ME, et al. Characteristics of cigarette smoking and quitting among university students in Syria. Prev Med 2004; 39: 330-6. [CrossRef]

25. Almerie MQ, Matar HE, Salam M, Morad A, Abdulaal M, Koudsi A, et al. Cigarettes and water pipe smoking among medical students in Syria: a cross-sectional study. IJTLD 2008; 12: 1085-91.

26. Haddad LG, Malak MZ. Smoking habits and attitudes towards smoking among university students in Jordan. IJNS 2002; 39: 793-802. [CrossRef]

27. Khader YS, Alsadi AA. Smoking habits among university students in Jordan: prevalence and associated factors. EMHJ 2008; 14: 897904.

28. Merrill RM, Madanat HN, Cox E, Merrill JM. Perceived effectiveness of counseling patients about smoking among medical students in Amman, Jordan. EMHJ 2009; I5: II80-91.

29. Senol Y, Donmez L, Turkay M, Aktekin M. The incidence of smoking and risk factors for smoking initiation in medical faculty students: Cohort study. BMC Public Health 2006; 6: 128. [CrossRef]

30. Tessier JF, Freour P, Crofton J, Kombou L. Smoking habits and attitudes of medical, students towards smoking and antismoking campaigns in fourteen European countries. Eur J Epidemiol 1989; 5: 311. [CrossRef]

31. Tyas SL, Pederson LL. Psychosocial factors related to adolescent smoking: a critical review of the literature. Tob Control 1998; 7: 40920. [CrossRef]

32. Maziak W. The global epidemic of water pipe smoking. Addict Behav 20II; 36: I-5. [CrossRef]

33. Akl EA, Gunukula SK, Aleem S, Obeid R, Jaoude PA, Honeine R, Irani $J$. The prevalence of water pipe tobacco smoking among the general and specific populations: a systematic review. BMC Public Health 20II; II: 244. [CrossRef]

34. Poyrazoglu S, Sarli S, Gencer Z, Gunay O. Water pipe (narghile) smoking among medical and non-medical university students in Turkey. Ups J Med Sci 2010; II5: 210-6. [CrossRef]

35. Alvur MT, Cinar N, Akduran F, Dede C. Fallacies about water-pipe use in Turkish university students-what might be the consequences. Asian Pac J Cancer Prev 2014; 15: 1977-80. [CrossRef]

36. Iribarren C, Tekawa IS, Sidney S, Friedman GD. Effect of cigar smoking on the risk of cardiovascular disease, chronic obstructive pulmonary disease, and cancer in men. N Engl J Med 1999; 340: 177380. [CrossRef]

37. Vupputuri S, Hajat C, Al-Houqani M, Osman O, Sreedharan J, Ali $\mathrm{R}$, et al. Midwakh/dokha tobacco use in the Middle East: Much to learn. Tob Control 2016; 25: 236-4l. [CrossRef]
38. Nelson DE, Davis RM, Chrismon JH, Giovino GA. Pipe smoking in the United States, 1965-1991: Prevalence and attributable mortality. Prev Med 1996; 25: 91-9. [CrossRef]

39. Farsalinos KE, Polosa R. Safety evaluation and risk assessment of electronic cigarettes as tobacco cigarette substitutes: a systematic review. Ther Adv Drug Saf 20l4; 5: 67-86. [CrossRef]

40. Chapman SL, Wu LT. E-cigarette prevalence and correlates of use among adolescents versus adults: a review and comparison. J Psychiatr Res 2014; 54: 43-54. [CrossRef]

4l. Tobacco Experts College. Introduction to tobacco. Istanbul: TEYO publication, 1978. p. 9- 18.

42. Baris I ed. Tobacco and health. First ed. Ankara: Ministry of Education publications; 1994. p. II-4.

43. Suben M. Tobacco fabrication. First ed. İstanbul: TEYO publication; 1989. p. 9-33.

44. Baris YI. History of tobacco use. Available from: http://www.toraks. org.tr/userfiles/file/TuTuN_KULLANIMININ_TARiHcESi-I_Baris. pdf. (Cited 2018 February 14)

45. Yilmaz S, Benzer F, Ozan S, Gurgoze SY. Oxidative damage and arginase activity in tissues of rats exposed to cigarette smoke. Revue De Médecine Vétérinaire 2008; 159: 79-86.

46. Demir B, Okutan M. Radioactive cigarettes: Tobacco and polonium-2I0 + lead-2I0. Türk Onkoloji Dergisi 2014; 29: 27-3I. [CrossRef]

47. Tekbas OF, Vaizoglu S, Guleç M, Guler C. Effect of smoking on the level of ionising radiation in student rooms. Indoor Built Environ 2003; 12: 197-200. [CrossRef]

48. Otan H, Apti R. Tobacco. Aegean Agricultural Research Institute Publications 1989; 83. 49. Hannoun A, Nassar AH, Usta IM, Abu Musa A. Effect of female narghile smoking on in vitro fertilization outcome. Eur J Obstet Gynecol Reprod Biol 2010; 150: 17|-4. [CrossRef]

50. An evaluation of cigarettes and other tobacco products in Turkey. 2015. Available from: http://www.tutuneksper.org.tr/kaynaklar/ ders-notlari/fabrikasyon/I05.

51. Official Gazette. Regulations on cigar and cigarillo import, their prices and internal marketing. Available from: http://www.resmigazete.gov.tr/eskiler/2008/04/200804l6-2.htm. (Cited 2018 February 17)

52. Suben M. Tobacco production. Ist edition. Istanbul: TEYO publication; 1989. p. 9-33.

53. Kilinc M, Okur E, Kurutas EB, Guler Fl, Yildirim I. The effects of Maras powder (smokeless tobacco) on oxidative stress in users. Cell Biochem Funct 2004; 22: 233-6. [CrossRef]

54. Peto R. Smoking and death: the past 40 years and the next $40 . \mathrm{BMJ}$ 1994; 309: 937-9. [CrossRef]

55. CDC Centers for Disease Control and Prevention. CDC24/7. Saving lives, protecting people. NIOSH. Nicotine: Systemic agent. Available from: https://www.cdc.gov/niosh/ershdb/emergencyresponsecard_29750028.html.

56. American Psychiatric Association. Diagnostic and Statistical Manval of Mental Disorders. Fourth Edition. Washington, DC: American Psychiatric Association, 2000. Available from: https://www.danya. com/dlc/bup/pdf/Dependence_DSM.PDF.

57. Klitzner M, Greunewald PJ, Bamberger E. The assesment of parent-lead prevention programs: A preliminary assessment of impact. J Drug Educ 1990; 20: 77-94. [CrossRef]

58. Biglan A. Ary D. Yudelsan H. Experimental evaluation of a modulator approach to mobilizing antitobacco influences of peers and parents. Am J Community Psychol 1996; 24: 311-39. [CrossRef]

59. Iglan A.Glesgow R. Arj D. Thompson R, Severson H, Lichtenstein $E$, et al. How generalizable are the effects of smoking prevention programs? Refusal skills training and parent messages in a teacher-administered program. J Behav Med 1987; 10: 613-28. [CrossRef]

60. McWhorter WP, Boyd GM, Mattson ME. Predictors of quitting smoking: the NHANES I followup experience. J Clin Epidemiol 1990; 43: 399-405. [CrossRef] 
61. Heatherton TF, Kozlowski LT, Frecker RC, Fagerström KO. Fagerstrom test for nicotine dependence: a revision of the Fagerstrom tolerance questionnaire. Br J Addict 1991; 86: III9-27. [CrossRef]

62. European Medical Association Smoking or Health (EMASH). Guidelines on smoking cessation for general practitioners and other health professionals. Monaldi Arch Chest Dis 1997; 52: 282-4.

63. Turkish Thoracic Association Tobacco Control Working Group. Consensus Document on Tobacco Cessation Diagnosis and Treatment. 2014; Miki Publications. Available from: https://www.medikalakademi.com.tr/?get_group_doc $=20 /$ I392485750-Sigara-BirakmaTani--ve-Tedavi-Uzlasi-Raporu-20l4.pdf.

64. Coe JW, Brooks PR, Vetelino MG, Wirtz MC, Arnold EP, Huang J, et al. Varenicline: An alpha 4 beta 2 nicotinic receptor partıal agonist for smoking cessatıon. J Med Chem 2005; 48: 3474-7. [CrossRef]

65. WHO Framework Convention on Tobacco Control. Available from: http://www.who.int/fctc/text_download/en/index.html.

66. World Health Organization. WHO report on the global tobacco epidemic, 2008: The MPOWER Package 2008. Available from: http://apps. who.int/iris/bitstream/I0665/43818/I/9789241596282_eng.pdf.

67. Kosku N, Koksu M, Cikrikcioglu U, Ozlen Z. The knowledge, attitudes and behaviours of the members of the Turkish Thoracic Association on smoking. Turk Thorac J 2003; 4: 223-30. 68. Dedeoglu N, Donmez $L$, Aktekin M. Tobacco use among health professionals in Antalya. Tobacco Alert for Health 1994; I: 7-II.

69. Tezcan S, Yardım N. Smoking status of doctors, nurses and medical students in some health institutions of Turkey. Tuberculosis and Thorax Journal 2003; 51: 390-7.

70. Ohida T, Sakurai H, Mochizuki Y, Kamal AMM, Takemura S, Minowa $M$, Kawahara K. Smoking prevalence and attitudes toward smoking among Japanese physicians. JAMA 200I; 285: 2643-8. [CrossRef]

71. Josseran L, King G, Velter A, Dressen C, Grizeau, D. Smoking behavior and opinions of French general practitioners. J Natl Med Assoc 2000; 92: 382-90.

72. Willaing I, Ladelund S. Smoking behavior among hospital staff still influences attitudes and counseling on smoking. Nicotine and Tobacco Research 2004; 6: 369-75. [CrossRef]

73. Samuels N. Smoking among hospital doctors in Israel and their attitudes regarding anti-smoking legislation. Public Health 1997; III: 285-8. [CrossRef]

74. Zwar NA, Richmond RL. Role of the general practitioner in smoking cessation. Drug and Alcohol Review 2006; 25: 21-6. [CrossRef]

75. Bal DG, Lloyd JC, Manley MW. The role of the primary care physician in tobacco use prevention and cessation, CA Cancer J Clin 1995; 45: 369-74. [CrossRef]

76. Uzaslan E. Cessation methods. Continuing Medical Education Journal (STED) 2003; 12: 166-7.

77. Soliman AS. Department of Epidemiology, University of Michigan School of Public Health, 2012 Egyptian Public Health Association, 5626 SPH I, 1415 Washington Heights, Ann Arbor, MI 48109, USA. Available from: https://sph.umich.edu/practice/index.html.

78. World Health Organisation Global status report on non- communicable diseases 20l4. Available from: http://www.who.int/nmh/ publications/ncd-status-report-2014/en/.

79. Working Group on Tobacco Control of the Association of Public Health Specialists, Turkey. Terms and definitions on tobacco control. HASUDER. Available from: http://hasuder.org.tr/hsg/?p=696. (Cited 2018 September 21)

80. The Data Blog. New country classifications by income level: 20172018. Available from: https://blogs.worldbank.org/opendata/ new-country-classifications-income-level-2017-2018.(Cited 25 Dec 2017)

81. World Health Organization (2017). WHO regional offices. Available from: http://www.who.int/about/regions/en/. (Cited 2017 December 24)

82. Armstrong GW, Veroonese G, George PF, Montroni I, Ugolini G. Assessment of tobacco habits, attitudes, and education among medi- cal students in the United States and Italy: A cross-sectional survey. J Prev Med Public Health 2017; 50: 177-87. [CrossRef]

83. La Torre G, Kirch W, Bes-Rastrollo M, Ramos RM, Czaplicki M, Gualano MR, et al. Tobacco use among medical students in Europe: Results of a multicentre study using the Global Health Professions Student Survey. Public Health 2012; 126: 159-64. [CrossRef]

84. Khan AA, Dey S, Taha AH, Huq FS, Moussawi AH, Omar OS, et al. Attitudes of Cairo University medical students toward smoking: the need for tobacco control programs in medical education, J Egypt Public Health Assoc 2012; 87: 1-7. [CrossRef]

85. Smith DR, Wada K. Declining rates of tobacco use in the Japanese medical profession 1965-2009. J Epidemiol 2013; 23: 4-II. [CrossRef]

86. Baykan Z, Nacar M. Tobacco use an attitudes regarding tobacco legislation among medical students. Dicle Med J 2014; 41: 483-90. [CrossRef]

87. Hitchman SC, Fong GT. Gender empowerment and female-to-male smoking prevalence ratios. Bulletin of the World Health Organization 20II; 89: 195-202. [CrossRef]

88. Apps.who.int. (2015). GHO|By category|Tobacco use-Data by World Bank Income Group. Available from: http://apps.who.int/ gho/data/view.main.1805WB?lang=en. (Cited 2017 December 25)

89. Casetta B, Videla AJ, Bardach A, Morello P, Soto N, Lee K, et al. Association between cigarette smoking prevalence and income level: A systematic review and meta-analysis. Nicotine Tob Res 2017; 19: 1401-7. [CrossRef]

90. Bobak M, Jha P, Nguyen S, Jarvis M, Mundial B. Poverty and Smoking. In: Tobacco Control in Developing Countries. Oxford University Press; Sep 2000. p. 4l-6l.

91. Near East University. Tuition Fees for the Academic Year of 20172018. Available from: https://neu.edu.tr/tuition-fees-for-the-academic-year-of-2017-2018/. (Cited 2017 December 25)

92. Townsend J, Roderick P, Cooper J. Cigarette smoking by socioeconomic group, sex, and age: Effects of price, income, and health publicity. BMJ 1994; 309: 923-7. [CrossRef]

93. De Walque D. Does education affect smoking behaviors? Evidence using the Vietnam draft as an instrument for college education. J Health Econ 2007; 26: 877-95. [CrossRef]

94. Giskes K, Kunst AE, Benach J, Borrell C, Costa G, Dahl E, et al. Trends in smoking behavior between 1985 and 2000 in nine European countries by education. J Epidemiol Community Health 2005; 59: 395-40l. [CrossRef]

95. Zhu T, Feng B, Wong S, Choi W, Zhu SH. A comparison of smoking behaviors among medical and other college students in China. Health Promot Int 2004; 19: 189-96. [CrossRef]

96. Alexopoulos EC, Jelastopulu E, Aronis K, Dougenis D. Cigarette smoking among university students in Greece: a comparison between medical and other students. Environ Health Prev Med 20I0; 15: II5-20. [CrossRef]

97. Filippidis FT, Vardavas Cl, Loukopoulou A, Behrakis P, Connolly GN, Tountas Y. Prevalence and determinants of tobacco use among adults in Greece: 4 year trends. Eur J Public Health 2012; 23: 772-6. [CrossRef]

98. Rigotti NA, Regan S, Majchrzak NE, Knight JR, Wechsler H. Tobacco use by Massachusetts public college students: long term effect of the Massachusetts Tobacco Control Program. Tob Control 2002; II (Suppl 2): ii20-4.

99. Richmond R, Zwar N, Taylor R, Hunnisett J, Hyslop F. Teaching about tobacco in medical schools: a worldwide study. Drug Alcohol Rev 2009; 28: 484-97. [CrossRef]

100. Richmond R, DebonoRD, Larcos D, Kehoe L. Worldwide survey of education on tobacco in medical schools. Tob Control 1998; 7:247-52. [CrossRef]

I0I. Springer CM, Tannert Niang KM, Matte TD, Miller N, Bassett MT, Frieden TR. Do medical students know enough about smoking to help their future patients? Assessment of New York City fourthyear medical students' knowledge of tobacco cessation and treatment for nicotine addiction. Acad Med 2008; 83: 982-9. [CrossRef]

102. Pederson LL, Blumenthal DS, Dever A, McGrady G. A web-based smoking cessation and prevention curriculum for medical students: why, how, what, and what next. Drug Alcohol Rev 2006; 25: 39-47. [CrossRef] 
103. Ockene JK, Hayes RB, Churchill LC, Crawford SL, Jolicoeur DG, Murray DM, et al. Teaching medical students to help patients quit smoking: Outcomes of a 10 -school randomized controlled trial. J Gen Intern Med 2016; 31: 172-8I. [CrossRef]

104. Hayes RB, Geller A, Churchill L, Jolicoeur D, Murray DM, Shoben $A$, et al. Teaching tobacco dependence treatment and counseling skills during medical school: rationale and design of the Medical Students helping patients Quit tobacco (MSQuit) group randomized controlled trial. Contemp Clin Trials 2014; 37: 284-93. [CrossRef]

105. Yamini TR, Nichter M, Nichter M, Sairu P, Aswathy S, Leelamoni K, et al. Developing a fully integrated tobacco curriculum in medical colleges in India. BMC Med Educ 2015; [CrossRef] 